\title{
Dimethylsulfoniopropionate (DMSP) and dimethyl sulfide (DMS) cycling across contrasting biological hotspots of the New Zealand subtropical front
}

\author{
Martine Lizotte $^{1}$, Maurice Levasseur ${ }^{1}$, Cliff S. Law ${ }^{2,3}$, Carolyn F. Walker ${ }^{2}$, Karl A. Saf ${ }^{4}$, Andrew Marriner ${ }^{2}$, and \\ Ronald P. Kiene ${ }^{5}$ \\ ${ }^{1}$ Université Laval, Department of biology (Québec-Océan), Québec City, Québec, Canada \\ ${ }^{2}$ National Institute of Water and Atmospheric Research, Wellington, New Zealand \\ ${ }^{3}$ University of Otago, Department of Chemistry, Dunedin, New Zealand \\ ${ }^{4}$ National Institute of Water and Atmospheric Research, Hamilton, New Zealand \\ ${ }^{5}$ University of South Alabama, Department of Marine Sciences, Mobile, AL, USA
}

Correspondence to: Martine Lizotte (martine.lizotte@qo.ulaval.ca)

Received: 2 May 2017 - Discussion started: 17 May 2017

Revised: 25 September 2017 - Accepted: 16 October 2017 - Published: 23 November 2017

\begin{abstract}
The oceanic frontal region above the Chatham Rise east of New Zealand was investigated during the late austral summer season in February and March 2012. Despite its potential importance as a source of marine-originating and climate-relevant compounds, such as dimethyl sulfide (DMS) and its algal precursor dimethylsulfoniopropionate (DMSP), little is known of the processes fuelling the reservoirs of these sulfur $(\mathrm{S})$ compounds in the water masses bordering the subtropical front (STF). This study focused on two opposing short-term fates of DMSP-S following its uptake by microbial organisms (either its conversion into DMS or its assimilation into bacterial biomass) and has not considered dissolved non-volatile degradation products. Sampling took place in three phytoplankton blooms (B1, B2, and B3) with B1 and B3 occurring in relatively nitraterich, dinoflagellate-dominated subantarctic waters, and B2 occurring in nitrate-poor subtropical waters dominated by coccolithophores. Concentrations of total DMSP (DMSP $\left.{ }_{t}\right)$ and DMS were high across the region, up to 160 and $14.5 \mathrm{nmol} \mathrm{L}^{-1}$, respectively. Pools of DMSP $_{\mathrm{t}}$ showed a strong association with overall phytoplankton biomass proxied by chlorophyll $a\left(r_{\mathrm{s}}=0.83\right)$ likely because of the persistent dominance of dinoflagellates and coccolithophores, both DMSP-rich taxa. Heterotrophic microbes displayed low S assimilation from DMSP (less than $5 \%$ ) likely because their $\mathrm{S}$ requirements were fulfilled by high DMSP availability. Rates of bacterial protein synthesis were significantly correlated
\end{abstract}

with concentrations of dissolved DMSP $\left(\mathrm{DMSP}_{\mathrm{d}}, r_{\mathrm{s}}=0.86\right)$ as well as with the microbial conversion efficiency of $\mathrm{DMSP}_{\mathrm{d}}$ into DMS (DMS yield, $r_{\mathrm{s}}=0.84$ ). Estimates of the potential contribution of microbially mediated rates of DMS production $\left(0.1-27 \mathrm{nmol} \mathrm{L}^{-1} \mathrm{day}^{-1}\right)$ to the near-surface concentrations of DMS suggest that bacteria alone could not have sustained DMS pools at most stations, indicating an important role for phytoplankton-mediated DMS production. The findings from this study provide crucial information on the distribution and cycling of DMS and DMSP in a critically under-sampled area of the global ocean, and they highlight the importance of oceanic fronts as hotspots of the production of marine biogenic $\mathrm{S}$ compounds.

\section{Introduction}

In oceanic waters, the gas dimethyl sulfide (DMS) is the predominant biogenic compound contributing to the flux of sulfur (S) from the hydrosphere to the atmosphere (Bates et al., 1992; Simó, 2001) with 17.6 to $34.4 \mathrm{Tg}$ of S estimated to be transferred annually (Lana et al., 2011). DMS has gained notoriety over several decades of research on the grounds of its potential role linking ocean biology and the climate (Andreae et al., 1985; Charlson et al., 1987; Lovelock et al., 1972), a role that is still under debate (Quinn 
et al., 2017; Quinn and Bates, 2011). Produced through the enzymatic cleavage of its marine algae-derived precursor, dimethylsulfoniopropionate (DMSP), DMS ventilates to the marine atmospheric boundary layer (Liss et al., 1997) where it is oxidized, mainly by the hydroxyl radical OH (Andreae and Crutzen, 1997). DMS oxidation products may influence the atmospheric radiative budget via their role in aerosol properties and cloud condensation as well as their contribution to a persistent stratospheric aerosol layer, or Junge layer (Gondwe et al., 2003; Marandino et al., 2013). The significance of DMS-derived particles in affecting the Earth's cloudiness and albedo is largely determined by the relative importance of atmospheric DMS oxidation products compared to other airborne particles originating from, for example, sea salts, dust, and anthropogenic pollutants (Quinn and Bates, 2011). As such, areas without significant dust or anthropogenic particle inputs may offer productive grounds for new particle formation emanating from DMS.

Because DMS is of biogenic origin, factors controlling the distribution and productivity of marine plankton play a large role in shaping DMS dynamics and standing stocks. Oceanic frontal and convergence zones are regions of intense mesoscale turbulence displaying enhanced levels of chlorophyll $a$ (Chl $a$ ) (Belkin et al., 2009) detectable from space (Weeks and Shillington, 1996). The heightened biological activity in these regions (Llido et al., 2005) is thought to lead to intensified carbon drawdown on seasonal timescales (Metzl et al., 1999) as well as high concentrations of DMS (Asher et al., 2017; Holligan et al., 1987; Matrai et al., 1996; Nemcek et al., 2008; Tortell, 2005; Tortell and Long, 2009). These productive regions sometimes form unique biogeographic habitats of their own such as the subtropical convergence province proposed by Longhurst (2007). Nearly encircling the entire globe in a meridional band between 35 and $45^{\circ} \mathrm{S}$, the subtropical convergence, or hereafter termed the subtropical front (STF), spreads for the most part across remote regions of the planet where anthropogenic sources of atmospheric compounds exert subordinate influence on local aerosol patterns compared to natural sources. Modellingbased evidence suggests that cloud condensation nuclei seasonality is driven mainly by DMS oxidation in this part of the ocean (Gondwe et al., 2003; Kloster et al., 2006; Vallina et al., 2006). Episodic phytoplankton bloom events in the STF occur mostly in austral spring-summer, with varying lifetimes of 8 to 60 days (Llido et al., 2005). Upon reaching the islands of New Zealand (NZ), the STF runs north along the eastern continental shelf break over the Chatham Rise, a relatively shallow $(250-350 \mathrm{~m})$ and productive seamount (Bradford-Grieve et al., 1997; Sutton, 2001).

While waters over Chatham Rise are recognized as biological hotspots (Rowden et al., 2005) supporting large phytoplankton blooms visible from space (Sadeghi et al., 2012), as well as accumulations of zooplankton and pelagic fish (Tracey et al., 2004), little is known of their productivity in terms of climate-relevant gases such as DMS. The latest
DMS climatological exercise by Lana et al. (2011) shows that for the New Zealand coastal (NEWZ) province only six data points are available (together averaging $<3 \mathrm{nmol} \mathrm{DMS} \mathrm{L}^{-1}$ ), with the temporal extent limited to the month of October. The biological cycling of DMS in this region thus remains surprisingly under-documented and mainly restricted to the continental shelf of New Zealand's North Island (Walker et al., 2000). The bordering ocean provinces comprised of the subantarctic water ring (SANT) and the south subtropical convergence (SSTC) have higher data coverage with greater temporal resolution, displaying monthly averages of approximately $5 \mathrm{nmol} \mathrm{DMS} \mathrm{L}^{-1}$ (December) and $10 \mathrm{nmol} \mathrm{DMS} \mathrm{L}^{-1}$ (January), respectively. These results suggest that greater variation in DMS concentration might be expected in the NEWZ province, a proposition confirmed by a recent study showing DMS concentrations in surface waters over Chatham Rise spanning an order of magnitude (from approximately 4 to $40 \mathrm{nmol} \mathrm{L}^{-1}$; see Walker et al., 2016). It is thus paramount to better constrain the factors that affect DMS concentrations in surface waters above topographic plateaus and in oceanic convergence zones in view of the potential for phytoplankton blooms in these biologically active systems.

Phytoplankton bloom dynamics, particularly their speciation and their growth phases, from onset to senescence, are thought to play major roles in shaping the distribution of DMS, firstly through the variable biosynthesis of DMSP by different members of the phytoplankton community (Keller, 1989; Matrai and Keller, 1994). DMSP production is a widespread process in phytoplankton but its magnitude varies substantially among taxa, from non-detectable among certain cyanobacteria and diatoms, to considerable amounts (up to $400 \mathrm{mmol} \mathrm{DMSP} \mathrm{L}^{-1}$ of cell volume) within groups such as dinoflagellates and prymnesiophytes (Keller, 1989). Furthermore, physicochemical conditions encountered by algal populations in their environment, such as nutrient repletion or depletion, doses of solar radiation, oxidative stresses, and modifications in salinity or temperature may also impact the production of DMSP, as algal cells upor down-regulate their production to cope with these external pressures (Simó, 2001; Stefels et al., 2007; Sunda et al., 2002). DMSP is released into the aqueous environment largely because of cell disruption following aging, grazing, or viral attack (Dacey and Wakeham, 1986; Turner et al., 1988) and, to a lesser extent, by healthy algae via active exudation (Laroche et al., 1999). Some non-DMSP producing algal species are thought to take up available dissolved DMSP directly from the medium and assimilate sulfur from DMSP through a process yet to be identified (Vila-Costa et al., 2006a).

Beyond its role as the precursor of DMS, DMSP also holds global biogeochemical significance as a prominent source of reduced S and carbon (C) for marine heterotrophic microorganisms (Kiene et al., 2000; Simó and Dachs, 2002). Depending on bacterial requirements for either $\mathrm{S}$ or $\mathrm{C}$ and 
the relative contribution of DMSP to the overall oceanic S pool (Kiene et al., 2000; Levasseur et al., 1996; Pinhassi et al., 2005), at least two very different and competing outcomes are involved from the bacterial catabolism of DMSP: one producing DMS, the potential climatic relevant gas, and the other producing methanethiol (MeSH), an important microbial substrate (Kiene and Linn, 2000b). Another potential fate for DMSP is its transformation into dissolved non-volatile degradation products (DNVSs), including sulfate $\left(\mathrm{SO}_{4}^{2-}\right)$; however, less is known of the molecular pathways involved in this process (Kiene and Linn, 2000b; Reisch et al., 2011). The relative importance of these competing pathways varies widely in nature, and the yield of DMS from DMSP (moles of DMS produced from moles of DMSP consumed) may vary from 2 to $100 \%$. The factors controlling them, however, are still poorly understood (Kiene et al., 2000; Simó and Pedrós-Alió, 1999). Bacterial production of DMS is not the sole pathway bolstering reservoirs of DMS in marine waters: certain species of autotrophic phytoplankton can also directly cleave DMSP into DMS. Although the particular enzymatic reactions that govern DMSP breakdown are not fully characterized (Todd et al., 2007), most reactions are attributed to DMSP lyases (Alcolombri et al., 2015; Schafer et al., 2010; Stefels et al., 2007). What controls the contribution of either process (autotrophic or heterotrophic DMSP to DMS conversion) in fuelling DMS stocks remains unclear but appears to vary extensively (Lizotte et al., 2012). While there are multiple sources of DMS, there are also multiple sinks, including bacterial consumption, sunlight oxidation, and finally a small fraction $(<10 \%)$ of the produced DMS that may ventilate to the marine boundary layer (Malin, 1997) where its oxidation products, namely sulfate aerosol particles, can potentially influence the Earth's radiation budget directly through solar backscattering and indirectly by seeding brighter and longer-lived clouds (Albrecht, 1989; Ångström, 1962; Charlson et al., 1987; Twomey, 1977).

Gaining insight into how marine microorganisms influence the Earth's atmosphere and climate are topics of prime interest for the international scientific community and at the core of investigations implemented by the Surface Ocean Aerosol Production (SOAP) programme (Law et al., 2017). Under the auspices of SOAP, this study specifically explored two competing bacterial DMSP catabolic processes: (1) DMSP cleavage (Visscher et al., 1991; Yoch et al., 1997), a non-S-assimilating pathway allowing bacteria to utilize the carbon contained in DMSP in the form of acrylate while the sulfur moiety is released as DMS (Kiene et al., 2000; Yoch, 2002), and (2) DMSP demethylation/demethiolation (Taylor and Gilchrist, 1991; Taylor and Visscher, 1996), a $\mathrm{S}$-assimilatory pathway leading to $\mathrm{MeSH}$ production, a portion of which is incorporated directly into methionine, and subsequently into proteins by marine bacteria (Kiene et al., 1999). The later pathway is thus linked to sulfur assimilation but also yields a methyl group that can be used as a carbon source (Kiene and Linn, 2000a; Yoch, 2002).
The present study was carried out during austral summer within three autotrophic blooms, each exhibiting varying phytoplankton assemblages and developmental stages, and sourced within the upper surface mixed layers of a section of the subtropical front over the Chatham Rise east of New Zealand. To our knowledge, the results presented here are the first rate measurements made in the highly productive ocean region east of New Zealand and provide much-needed information on the concentrations and cycling of DMS and DMSP in connection to the "microbial maze" (Malin, 1997) in frontal zones.

\section{Methodological approach}

\subsection{Oceanographic setting}

Large-scale remote sensing through MODIS (Aqua and Terra) and underway instrumentation for $\mathrm{Chl} a, p \mathrm{CO}_{2}, \lambda 660$ backscatter, and DMS were employed to detect biologically productive areas near the Mernoo Gap and the eastern end of the Chatham Rise (see Table 1 as well as Bell et al., 2015 and Law et al., 2017 for further details on voyage track, location map, and biogeochemical characteristics of the sampling area). Briefly, areas located between 43 and $45^{\circ} \mathrm{S}$ east of New Zealand were evaluated for relevant bloom bio-indicators, and hotspots were marked by a drifting spar buoy for further subsampling. Three distinct blooms were identified and each was followed during relatively short ( $<10$ days) Lagrangian-type surveys. Nomenclature used by Bell et al. (2015) and Law et al. (2017) to describe these three sampling clusters, i.e. bloom 1, bloom 2, and bloom 3 (hereafter referred to as clusters B1, B2, and B3), are also used in this paper to simplify cross-referencing and data comparisons. The SOAP blooms were coherent, discrete areas of elevated ocean colour identified in satellite images characterized by a minimum of $1 \mathrm{mg} \mathrm{m}^{-3} \mathrm{Chl} a$ or higher. Sampling took place near the centre of these blooms but also at stations on the periphery and outside the blooms (Table 1), as defined by the distance from the bloom centre determined from pre-site surveys with bloom centre marked by a drifting spar buoy (see Law et al., 2017). Note that stations adjacent to the blooms were also located in generally productive waters (Table 1).

Solar radiation dose (SRD in $\mathrm{W} \mathrm{m}^{-2}$ ) was calculated using Eq. (1):

$\mathrm{SRD}=\left(I_{0} / k \cdot \mathrm{MLD}\right) \cdot\left(I-e^{-k \cdot \mathrm{MLD}}\right)$,

where $I_{0}$ represents the daily-averaged irradiance of the $24 \mathrm{~h}$ prior to sampling (in $\mathrm{W} \mathrm{m}^{-2}$ ) measured using an Eppley Precision Spectral Pyranometer (285-2800 nm); $k$ values (in $\mathrm{m}^{-1}$ ) are estimates of vertical diffuse attenuation coefficients based on photosynthetically active radiation (PAR) offset between two depths ( 2 and $10 \mathrm{~m})$; MLD is the mixed layer depth defined as the point at which a $0.2{ }^{\circ} \mathrm{C}$ difference 


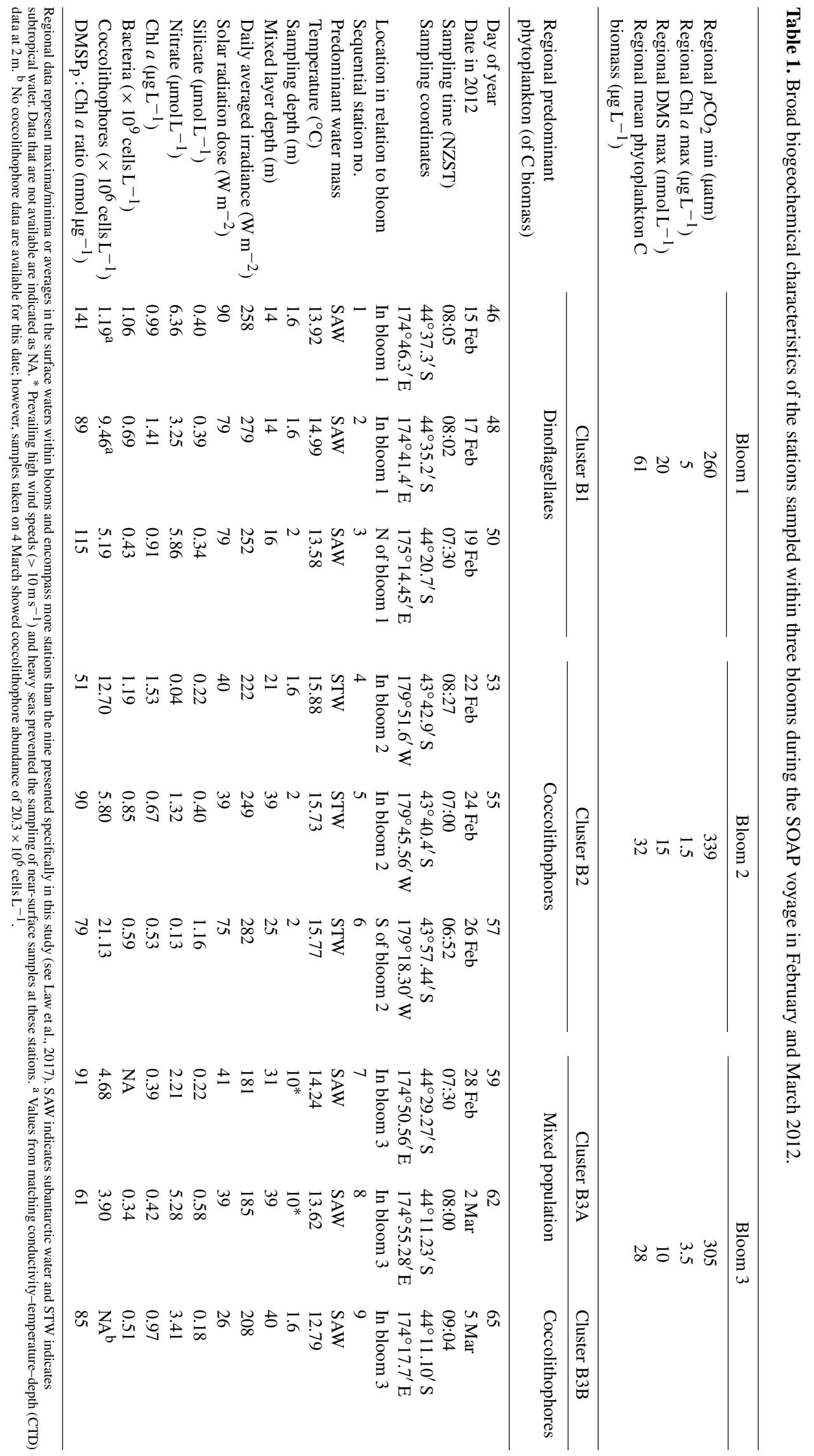


from the sea surface temperature occurred and was calculated according to Kara et al. (2000).

Ambient nitrate $\left(\mathrm{NO}_{3}^{-}\right)$concentrations were measured using colorimetric detection by segmented autoanalyser as described by Law et al. (2011). Total Chl $a$ (Whatman glass fibre GF/F filtered) concentrations were determined using $90 \%$ acetone extraction by the fluorometric technique with a Turner Designs fluorometer after Strickland and Parsons (1972). Bacterial samples were snap-frozen in liquid nitrogen (Lebaron et al., 1998) and thawed immediately before counting by flow cytometry shortly after the cruise following the methods described in Safi et al. (2007). Coccolithophore abundance in near-surface waters was determined using optical microscopy as described in Chang and Northcote (2016). No further information regarding the abundance of eukaryotic organisms in near-surface waters is available; however, the abundance and carbon content of other groups of phytoplankton in surface waters will be discussed in a separate paper relating DMS cycling and marine biogeochemistry (C. Law, personal communication, 2017).

\subsection{Microbial DMSP catabolism incubations}

Surface seawater samples were collected from a rigid-hulled inflatable boat away from the ship, between 07:00 and 09:00 NZST (New Zealand Standard Time) in the morning, with a novel apparatus dubbed "the sipper". The latter consists of a floating tubing array with peristaltic pump allowing the sampling of the uninterrupted first $1.6 \mathrm{~m}$ of the upper mixed layer waters (Walker et al., 2016). Nearsurface water was collected in a $2 \mathrm{~L}$ high-density polyethylene (HDPE) bottle and subsampling of variables (except for in situ DMS; see further details below) took place on the ship typically within $1-2 \mathrm{~h}$ of collection. As with most sampling procedures, potential bottle/handling effects associated with the sipper-collection method cannot be completely ruled out. When oceanographic conditions did not permit the deployment of the sipper (higher swell and wind speeds $>10 \mathrm{~m} \mathrm{~s}^{-1}$ ), surface seawater samples were collected directly from the ship with Niskin bottles mounted to a conductivity-temperature-depth (CTD) rosette (water depth corresponding to approximately 2 to $10 \mathrm{~m}$ on days of high wind speeds). Comparative studies completed on surface seawater collected from both the sipper and the Niskin bottles showed no significant differences in biological variables such as concentrations of DMS (Walker et al., 2016). Water samples were passed gently through a $210 \mu \mathrm{m}$ Nitex mesh by gravity to remove large zooplankton.

Following water collection, several types of incubation experiments were conducted aboard the ship to investigate microbial DMSP uptake and metabolism. Using the ${ }^{35} \mathrm{~S}$ $\mathrm{DMSP}_{\mathrm{d}}$ radiotracer approach, we monitored and quantified several microbial pathways of the degradation of $\mathrm{DMSP}_{\mathrm{d}}$, including the $\mathrm{DMSP}_{\mathrm{d}}$ loss rate constant $\left(k_{\mathrm{DMSP}_{\mathrm{d}}}\right.$, a measure of the scavenging rate by bacteria of the substrate $\mathrm{DMSP}_{\mathrm{d}}$ ), following protocols described by Kiene and Linn (2000b) and modifications by Slezak et al. (2007). In brief, water samples were transferred into duplicate $71 \mathrm{~mL}$ dark HDPE Nalgene bottles and tracer amounts $\left(<5 \mathrm{pmol} \mathrm{L}^{-1}\right)$ of ${ }^{35} \mathrm{~S}$ $\mathrm{DMSP}_{\mathrm{d}}$ were added to obtain a signal of approximately $1000 \mathrm{dpm} \mathrm{mL} \mathrm{m}^{-1}$. Total initial activity was first determined after gentle mixing of the bottles and subsampling of $1 \mathrm{~mL}$ into a $10 \mathrm{~mL}$ scintillation vials containing a $5 \mathrm{~mL}$ Ecolume ${ }^{\mathrm{TM}}$ liquid scintillation cocktail. The bottles were then incubated for $3 \mathrm{~h}$ at in situ temperature during which time $1 \mathrm{~mL}$ subsamples were taken after $0,30,60$, and $180 \mathrm{~min}$ and transferred into $10 \mathrm{~mL}$ scintillation vials containing $5 \mathrm{~mL}$ Ecolume $^{\mathrm{TM}}$ in order to measure the loss of ${ }^{35} \mathrm{~S}$-DMSP $\mathrm{d}$ over time (the disappearance of ${ }^{35} \mathrm{~S}-\mathrm{DMSP} \mathrm{d}_{\mathrm{d}}$ representing the consumption of this pool). The $k_{\mathrm{DMSP}_{\mathrm{d}}}$ was then calculated as the slope of the natural $\log$ of the fraction of remaining ${ }^{35} \mathrm{~S}_{-} \mathrm{DMSP}_{\mathrm{d}}$ versus time. Blank abiotic controls were performed at the very beginning of the incubation experiments as well as a second time at mid-cruise using $0.2 \mu \mathrm{m}$ filtered seawater treated with ${ }^{35} \mathrm{~S}_{-} \mathrm{DMSP}_{\mathrm{d}}$. Loss rates in the filtered controls were below $0.4 \%$ of those in live samples, indicating that extracellular enzyme activity was not important in $\mathrm{DMSP}_{\mathrm{d}}$ loss.

Determination of the $\mathrm{DMSP}_{\mathrm{d}}$-to-DMS conversion efficiency (DMS yield as measured by the recovery of ${ }^{35} \mathrm{~S}$ DMSP $_{d}$ as ${ }^{35} \mathrm{~S}$ volatiles) was conducted via parallel $24 \mathrm{~h}$ incubations. Tracer amounts $\left(<5\right.$ pmol L $\left.{ }^{-1}\right)$ of ${ }^{35}{ }^{S-D M S P}{ }_{d}$ were added to duplicate $71 \mathrm{~mL}$ dark HDPE Nalgene bottles containing seawater samples in which unlabelled DMS was added at a final concentration of $100 \mathrm{nmol} \mathrm{L}^{-1}$ to allow the determination of the gross ${ }^{35} \mathrm{~S}$-DMS production. Initial total activity was monitored as described previously. The bottles were incubated at in situ temperature for approximately $24 \mathrm{~h}$, until $>90 \%$ of the ${ }^{35} \mathrm{~S}_{-\mathrm{DMSP}_{\mathrm{d}}}$ was consumed (Slezak et al., 2007). Upon termination of the incubation, $5 \mathrm{~mL}$ of the sample was transferred into a $100 \mathrm{~mL}$ serum vial amended with $0.1 \mathrm{~mL}$ sodium dodecyl sulfate (SDS), $200 \mathrm{nmol} \mathrm{L}^{-1}$ unlabelled $\mathrm{DMSP}_{\mathrm{d}}$ to prevent further uptake and degradation of ${ }^{35} \mathrm{~S}_{-\mathrm{DMSP}}$, and $0.05 \mathrm{~mL}$ Ellman's reagent (to complex thiols such as methanethiol). Following the transfer of the samples into the serum vials, the bottles were quickly sealed with a rubber stopper fitted with a well cup holding a type-A/E glass fiber filter soaked with $0.2 \mathrm{~mL}$ stabilized $\mathrm{H}_{2} \mathrm{O}_{2}(3 \%)$. The vials were set to trap the volatile ${ }^{35} \mathrm{~S}$ on an orbital shaker and stirred at $100 \mathrm{rpm}$ for approximately $6 \mathrm{~h}$ (Kiene and Linn, 2000b). After trapping was complete, the filter wicks were removed and placed in Ecolume ${ }^{\mathrm{TM}}$ scintillation fluid for counting. ${ }^{35} \mathrm{~S}$ activity on the filters was considered to be ${ }^{35} \mathrm{~S}$-DMS because the Ellman's reagent makes other sulfur gases (e.g. methanethiol) non-volatile. After the volatiles were trapped, a new stopper with $\mathrm{H}_{2} \mathrm{O}_{2}$-soaked filter was placed in the vial. Each vial was then injected with $0.2 \mathrm{~mL} \mathrm{NaOH}(5 \mathrm{~N})$ through the stopper using a BD precision guide needle to quantitatively cleave remaining ${ }^{35} \mathrm{~S}$ $\mathrm{DMSP}_{\mathrm{d}}$ into ${ }^{35} \mathrm{~S}$-DMS (a pool known as the unconsumed ${ }^{35} \mathrm{~S}-\mathrm{DMSP} \mathrm{d}_{\mathrm{d}}$ ). The ${ }^{35} \mathrm{~S}-\mathrm{DMS}$ was trapped as described above. 
The DMS yield was calculated from the fraction of added ${ }^{35} \mathrm{~S}$ recovered as ${ }^{35} \mathrm{~S}$-DMS in the live incubation divided by the fraction of ${ }^{35} \mathrm{~S}$-DMSP consumed during the incubation.

To estimate the incorporation of ${ }^{35} \mathrm{~S}-\mathrm{DMSP}_{\mathrm{d}}$ into macromolecules (sulfur assimilation efficiency), duplicate $5 \mathrm{~mL}$ subsamples were also taken from the previous $24 \mathrm{~h}$ incubation bottles and gently filtered by manual pumping through a $0.2 \mu \mathrm{m}$ Nylon filter and then rinsed with trichloroacetic acid (TCA) as described in Kiene and Linn (2000b). The filters were placed in $10 \mathrm{~mL}$ scintillation vials containing $5 \mathrm{~mL}$ Ecolume $^{\mathrm{TM}}$ and the radioactivity remaining on TCA-rinsed filters was later quantified by liquid scintillation counting. Finally, each ${ }^{35} \mathrm{~S}$ pool measurement was expressed as a frac-

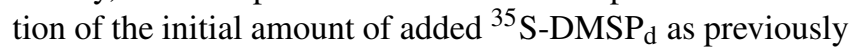
described. The measurement of the above variables allowed us to estimate $\mathrm{DMSP}_{\mathrm{d}}$ loss rate constants $\left(k_{\mathrm{DMSP}_{\mathrm{d}}}\right), \mathrm{DMSP}_{\mathrm{d}}$ turnover rates (or consumption rates) by multiplying values of $k_{\mathrm{DMSP}_{\mathrm{d}}}$ with in situ DMSP $\mathrm{d}$ concentration, and rates of gross DMS production from $\mathrm{DMSP}_{\mathrm{d}}$ by multiplying values of $\mathrm{DMSP}_{d}$ turnover rates with DMS yields. We calculated the propagation of uncertainty for rates that represent estimations based on other measured variables by adding the relative error of each variable in quadrature and expressing them as percentages. The uncertainty associated with estimates of $\mathrm{DMSP}_{\mathrm{d}}$ turnover rates and DMS production rates from $\mathrm{DMSP}_{\mathrm{d}}$ were on average 35 and $37 \%$, respectively. Furthermore, we cannot rule out any bottle effects during the incubation experiment, nor can we dismiss potential filtration artefacts related to the determination of $\mathrm{DMSP}_{\mathrm{d}}$ concentrations that the derived estimates are based on. However, all measurements were made following the best practices published and available at the time of sampling. Finally, the microbial transformation rates of $\mathrm{DMSP}_{\mathrm{d}}$ measured during these incubations are considered to stem mostly from bacterial processes; however, phytoplankton-related processes cannot be totally excluded as low DMSP-producing phytoplankton and picophytoplankton have been shown to assimilate DMSP $_{d}$ sulfur (Malmstrom et al., 2005; Ruiz-González et al., 2011; Vila-Costa et al., 2006b).

Bacterial biomass production rates were measured by the incorporation of ${ }^{3} \mathrm{H}$-leucine into TCA-insoluble particles. Samples were incubated in the dark for $4 \mathrm{~h}$ in sterile test tubes, at ambient water temperatures and processed using standard protocols (Simon and Azam, 1989). The average coefficient of variation $(\mathrm{CV})$ of $\left[{ }^{3} \mathrm{H}\right]$-leucine incorporation rates for triplicate samples was approximately $10 \%$. Rates of bacterial biomass production ( $\mu \mathrm{g}$ of $\mathrm{CL}^{-1} \mathrm{day}^{-1}$ ) were estimated by using a ratio of cellular carbon to protein in bacterial cells of 0.86 (Simon and Azam, 1989). Analysis of all radioactive samples $\left({ }^{35} \mathrm{~S}\right.$ and $\left.{ }^{3} \mathrm{H}\right)$ was conducted in NIWA-Hamilton (NZ) on a Packard Tri-Carb liquid scintillation counter immediately following the end of the cruise.

It has been suggested that light history and differential doses of solar radiation may impact the growth and activity of bacteria (Herndl et al., 1993) and potentially the fate of dissolved DMSP in seawater (Ruiz-González et al., 2012; Slezak et al., 2001, 2007; Toole et al., 2006). To evaluate this, we exposed near-surface communities to different light histories for $6 \mathrm{~h}$ prior to ${ }^{35} \mathrm{~S}$-DMSP $\mathrm{d}_{\mathrm{d}}$-enriched bioassays: ambient variable light (using quartz bottles in deck board incubators) or acclimation to darkness (using dark HDPE Nalgene bottles). Rates were thus obtained during post-exposure dark incubations (as explained above) conducted after $6 \mathrm{~h}$ preincubations at ambient light or in the dark. Because the communities were sourced in near-surface waters during daylight hours, the incubations conducted in quartz bottles are thought to be representative of the natural and variable light experienced by these biological communities at the surface of the ocean. On the whole, the light conditions (dark and ambient) at which the cells were pre-acclimated for $6 \mathrm{~h}$ had no significant effect on the ${ }^{35} \mathrm{~S}-\mathrm{DMSP}_{\mathrm{d}}$ metabolic rates measured. This result contrasts with findings from earlier studies (such as Galí et al., 2011; Ruiz-González et al., 2012; Slezak et al., 2001, 2007; Toole et al., 2006) and could be related to a number of variables such as the timing and depth of sampling, the type of bacterial assemblages present, and their previous light history, as well as the different temporal and spatial scales at which exposure to solar radiation varies (Ruiz-González et al., 2013). Because of these wide-ranging and intricate lightbacteria interactions, natural solar radiation is believed to play a significant, yet challenging to predict, role in modulating bacterial dynamics and biogeochemical functions (RuizGonzález et al., 2013). In the current study, the sulfur-related metabolic activities of the marine biota sourced in the morning (between approximately 07:00 and 09:00 NZST; Table 1) from the highly irradiated near-surface waters may have persisted in the dark within the time period of experimental preexposure (6h); however, the lack of information on the phylogeny of bacterial groups present, for example, hampers a more detailed discussion. We therefore present rate measurements made in dark-incubated samples that had been preexposed to ambient light conditions for $6 \mathrm{~h}$.

\subsection{Concentrations of $S$ compounds}

Duplicate samples of in situ dissolved DMSP $\left(\mathrm{DMSP}_{\mathrm{d}}\right)$ and total DMSP $\left(\mathrm{DMSP}_{\mathrm{t}}=\mathrm{DMSP}_{\mathrm{p}}+\mathrm{DMSP}_{\mathrm{d}}\right)$ were collected aboard the ship using the non-perturbing small-volume gravity drip filtration (SVDF) procedure (Kiene and Slezak, 2006). For $\mathrm{DMSP}_{d}$ samples, approximately $25 \mathrm{~mL}$ of seawater were gravity filtered onto $\mathrm{GF} / \mathrm{F}$ and the first $3.5 \mathrm{~mL}$ of samples were kept in $5 \mathrm{~mL}$ falcon tubes amended with $50 \mu \mathrm{L} 50 \% \mathrm{H}_{2} \mathrm{SO}_{4}$ and maintained in the dark at $4{ }^{\circ} \mathrm{C}$. For DMSP $_{t}, 3.5 \mathrm{~mL}$ of the unfiltered water sample were transferred directly into $5 \mathrm{~mL}$ falcon tubes and treated the same way as $\mathrm{DMSP}_{\mathrm{d}}$ samples. Subsequent analysis took place at Laval University (Canada) through alkali treatment to cleave DMSP into DMS, purging, cryotrapping, and sulfur-specific gas chromatography (GC; see Lizotte et al. 2012). Duplicate in situ DMS samples were collected directly from the sipper 
or the Niskin bottles by overflowing two volumes of seawater in $150 \mathrm{~mL}$ crimp-top glass bottles and were analysed aboard the ship within less than $5 \mathrm{~h}$ of collection following methods described in detail by Walker et al. (2016). Briefly, calibrated volumes $(5 \mathrm{~mL})$ of seawater samples were purged with zerograde nitrogen (99.9\% pure) and gas-phase DMS was cryogenically concentrated on 60/80 Tenax TA in a stainless steel trap maintained at $-20^{\circ} \mathrm{C}$ via a cold finger connected to a cryocooling unit, then thermally desorbed at $100^{\circ} \mathrm{C}$ for analysis by a GC coupled with sulfur chemiluminescent detection. DMS samples were also collected in $23 \mathrm{~mL}$ serum vials at T0 and T6 during $6 \mathrm{~h}$ incubation experiments conducted in quartz bottles on the deck of the ship (at in situ light and temperature conditions) and processed as described above.

\subsection{Statistical analysis}

Statistical analyses were carried out using the Systat statistical software for Windows version 12.0 and Microsoft Office Excel for Mac 2011. Normality in data distribution was determined using Kolmogorov-Smirnov tests, following which Model II linear regressions and Spearman rank correlation coefficients were used to evaluate the relationships between variables (Legendre and Legendre, 1998; Sokal and Rohlf, 1995). Paired Student $t$ tests provided hypothesis assessments of the difference between treatments.

Considering the various environmental conditions encountered during the SOAP voyage, our dataset relied on the use of two different seawater collection approaches: the sipper method (Walker et al., 2016) and the more standard use of Niskin bottles mounted on a CTD rosette when periods of higher wind speeds and greater sea state prevented the deployment of the sipper sampling equipment. Using a Wilcoxon signed-ranks test for paired samples with nonparametric distributions, Walker et al. (2016) showed that no significant differences $(p=1, \alpha=0.5)$ were detected between samples of DMS collected via the sipper method and those collected using Niskin bottles. This result, along with the presence of well-mixed surface waters (MLD ranging from 14 to $40 \mathrm{~m}$; Table 1), justified the pooling of measurements made in the surface waters resulting from the two approaches presented in the current study.

\section{Results}

\subsection{Environmental setting and biogeochemical background}

Broad-scale use of ocean colour images coupled to a suite of underway sensors allowed the successful location of three distinct blooms with varying signatures of phytoplankton speciation and biogeochemical backgrounds (see Fig. 1, as well as Bell et al., 2015 and Law et al., 2017 for further details on locations of blooms and a map of the cruise track). A few general characteristics of the surface waters within sam-
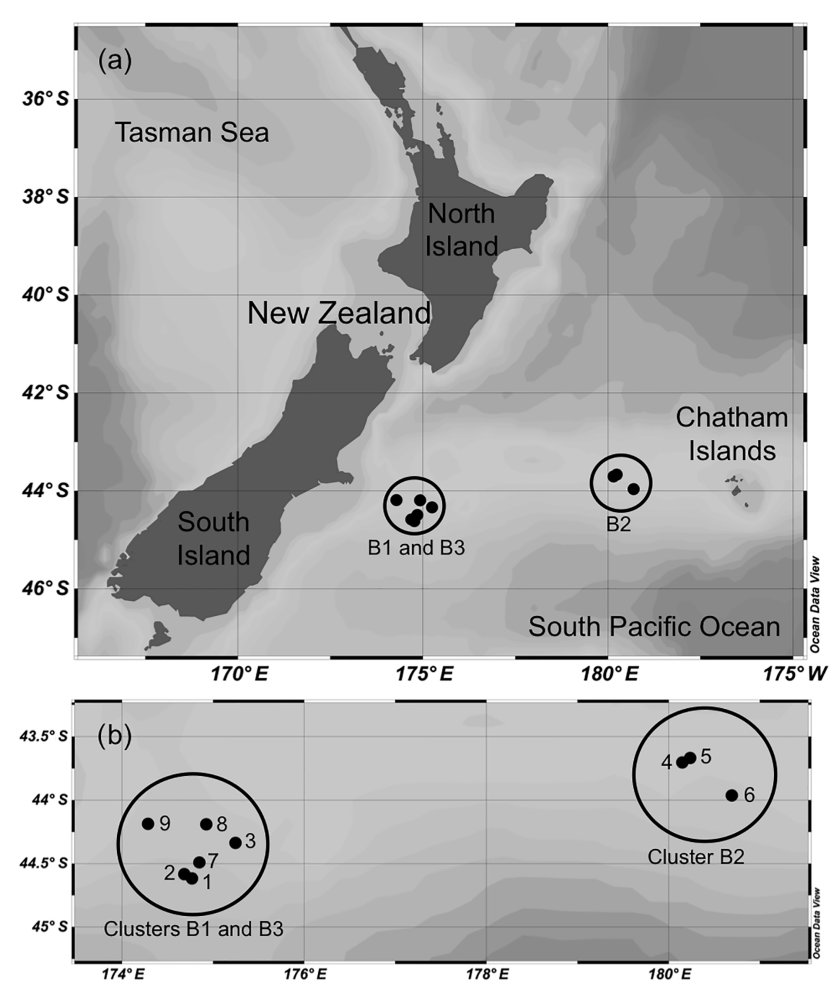

Figure 1. (a) Map of the general sampling area over the Chatham Rise east of New Zealand's South Island, and (b) close-up of the partitioning of the nine stations in clusters B1, B2, and B3 sampled during the SOAP voyage in February and March 2012.

pled blooms are presented in Table 1 to provide an overview of the oceanographic context for the nine stations specifically sampled in this study (see Law et al., 2017 for a more detailed description of the study area).

A first cluster of three stations (B1) was sampled between 15 and 19 February inside stations 1-2 and north of station 3 (Fig. 1). Located in a region exhibiting subantarctictype waters, B1 was characterized by the dominance of dinoflagellates (approximately $53 \%$ of total C biomass) with Gymnodinium spp. being responsible for an overall average of $30 \%$ of the total dinoflagellate $\mathrm{C}$ biomass (Table 1). Stations 1,2 , and 3 sampled in B1 displayed an average temperature of $14.2^{\circ} \mathrm{C}$, surface concentrations of $\mathrm{NO}_{3}^{-}$ranging between 3.25 and $6.36 \mu \mathrm{mol} \mathrm{L}^{-1}$ (mean $5.16 \mu \mathrm{mol} \mathrm{L}^{-1}$ ), and concentrations of Chl $a$ varying from 0.91 to $1.41 \mu \mathrm{g} \mathrm{L}^{-1}$ (mean $1.1 \mu \mathrm{g} \mathrm{L}^{-1}$ ). Bacterial abundance ranged from 0.43 to $1.06 \times 10^{9}$ cells L ${ }^{-1}$.

The cruise track then extended further east near the Chatham Islands to capture a coccolithophore-dominated bloom (approximately $41 \%$ of total C biomass) located in subtropical waters. In this area, a second cluster of three stations was sampled between 22 and 26 February with stations 4 and 5 inside B2 and station 6 located south of B2. Temperatures in surface waters were slightly warmer (mean $15.8^{\circ} \mathrm{C}$ ) than stations in B1. Stations 4 
to 6 exhibited low stocks of $\mathrm{NO}_{3}^{-}$ranging from 0.04 to $1.32 \mu \mathrm{mol} \mathrm{L}^{-1}$ (mean $0.5 \mu \mathrm{mol} \mathrm{L}^{-1}$ ) while near-surface concentrations of Chl $a$ varied between 0.53 and $1.53 \mu \mathrm{g} \mathrm{L}^{-1}$ (mean $0.91 \mu \mathrm{g} \mathrm{L}^{-1}$ ). Bacterial abundance varied between 0.59 and $1.19 \times 10^{9}$ cells $\mathrm{L}^{-1}$ throughout the B2 sampling stations.

After sampling B2, the cruise path returned to the west near the first cluster of stations sampled within subantarcticdominated waters. This third cluster, referred to as B3 (stations 7-9), was sampled during 28 February and 5 March. Stations in B3 were characterized by an initial mixed phytoplankton population consisting of coccolithophores, small flagellates, and dinoflagellates (B3A; Table 1) that progressively favoured coccolithophore biomass towards the end of the sampling period (B3B). Surface temperatures were the lowest measured during the study, with a cluster average of $13.6{ }^{\circ} \mathrm{C}$. Surface water concentrations of $\mathrm{NO}_{3}^{-}$at stations 7 to 9 ranged from 2.21 to $5.28 \mu \mathrm{mol} \mathrm{L}^{-1}$ (mean of $3.63 \mu \mathrm{mol} \mathrm{L}^{-1}$ ) and concentrations of Chl $a$ varied between 0.39 and $0.97 \mu \mathrm{g} \mathrm{L}^{-1}$ (mean $0.59 \mu \mathrm{g} \mathrm{L}^{-1}$ ). Bacterial abundances were 0.34 and $0.51 \times 10^{9}$ cells L $^{-1}$ at stations 8 and 9 , respectively (no data are available for station 7 ; Table 1).

A transition towards deeper mixed layer depths from clusters B1 to B2 to B3 was apparent during the sampling period, with cluster average MLDs of $15 \pm 1,28 \pm 9$, and $37 \pm 5 \mathrm{~m}$, respectively (Table 1). Trends in daily-averaged irradiance generally exhibited a decrease between clusters, with averages ranging from $263 \pm 14\left(\mathrm{~W} \mathrm{~m}^{-2}\right)$ in $\mathrm{B} 1$, to $251 \pm 30$ $\left(\mathrm{W} \mathrm{m}^{-2}\right)$ in B2, and finally to $192 \pm 15\left(\mathrm{~W} \mathrm{~m}^{-2}\right)$ in B3 (Table 1). Patterns of SRD were very similar to those of dailyaveraged irradiance, showing a decreasing trend from the first cluster towards the last cluster sampled.

\subsection{Reservoirs of sulfur compounds across sampling clusters}

In situ sea surface reservoirs of DMSP $_{t}$ displayed a 5fold span across the study region (Fig. 2a). Highest DMSP concentrations were observed in $\mathrm{B} 1$, with values ranging from 118 to $160 \mathrm{nmol} \mathrm{L}^{-1}$ (Fig. 2a). It is also within $\mathrm{B} 1$ that the highest DMSP $_{\mathrm{p}}$ to Chl $a$ ratios occurred, with a range of 89 to $141 \mathrm{nmol} \mathrm{\mu g}^{-1}$ (Table 1). Stations sampled within $\mathrm{B} 2$ exhibited intermediate $\mathrm{DMSP}_{\mathrm{t}}$ pools varying from 45 to $97 \mathrm{nmol} \mathrm{L}^{-1}$ and ratios of DMSP $\mathrm{p}_{\mathrm{p}}$ to Chl $a$ that ranged from 51 to $90 \mathrm{nmol} \mathrm{\mu g}^{-1}$ (Table 1). Surface water DMSP $\mathrm{t}_{\mathrm{t}}$ concentrations within $\mathrm{B} 3$ were generally lower,

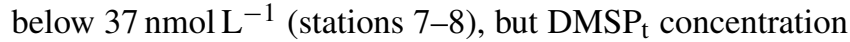
reached $92 \mathrm{nmol} \mathrm{L}^{-1}$ in the last station (station 9). Despite marked differences in concentrations of DMSP $\mathrm{P}_{\mathrm{t}}$ between stations 7-8 and station 9, ratios of DMSP $\mathrm{p}_{\mathrm{p}}$ to Chl $a$ were similar within this third cluster (range of 61 to $91 \mathrm{nmol} \mathrm{\mu g}^{-1}$; Table 1) due to the high $\mathrm{Chl} a$ concentration measured at station 9.

Patterns of $\mathrm{DMSP}_{\mathrm{d}}$ were broadly similar to those observed for $\mathrm{DMSP}_{t}$, albeit higher variability was evident from the

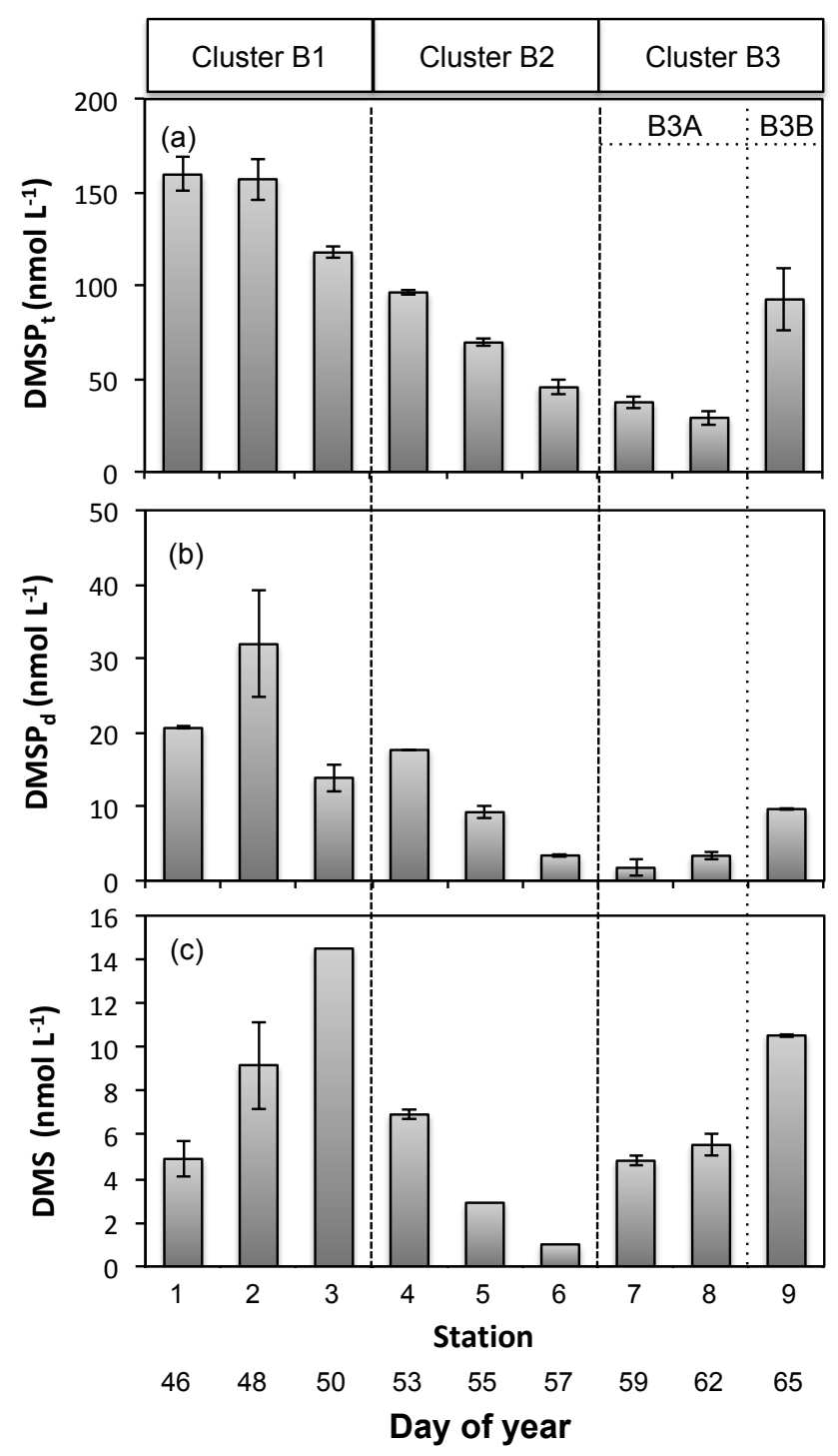

Figure 2. Concentrations of (a) total DMSP $\left(\mathrm{DMSP}_{\mathrm{t}}\right)$, (b) dissolved DMSP $\left(\right.$ DMSP $\left._{d}\right)$, and (c) DMS measured at nine stations during the SOAP voyage in February and March 2012. Values are means of experimental duplicates and error bars represent the absolute deviations of data points from their mean. DMS data from stations 3 , 5 , and 6 represent single samples, while values from stations 7 and 8 come from matching T0 DMS values (from incubation experiments). The three sampling clusters are noted as B1, B2, and B3.

18 -fold difference measured between the highest and lowest concentrations (Fig. 2b). Surface seawater within sampling cluster B1 had very high concentrations of $\mathrm{DMSP}_{\mathrm{d}}$ varying between 14 and $32 \mathrm{nmol} \mathrm{L}^{-1}$. Stations sampled in B2 presented $\mathrm{DMSP}_{\mathrm{d}}$ concentrations ranging between 3 and $18 \mathrm{nmol} \mathrm{L}^{-1}$. DMSP $\mathrm{d}_{\mathrm{d}}$ concentrations were below $3 \mathrm{nmol} \mathrm{L}^{-1}$ at stations $7-8$ while DMSP $_{\mathrm{d}}$ was $10 \mathrm{nmol} \mathrm{L}^{-1}$ at station 9 .

Concentrations of near-surface DMS also showed high variability, with a 14-fold spread within the stations sampled (Fig. 2c). Some of the highest values of DMS were 


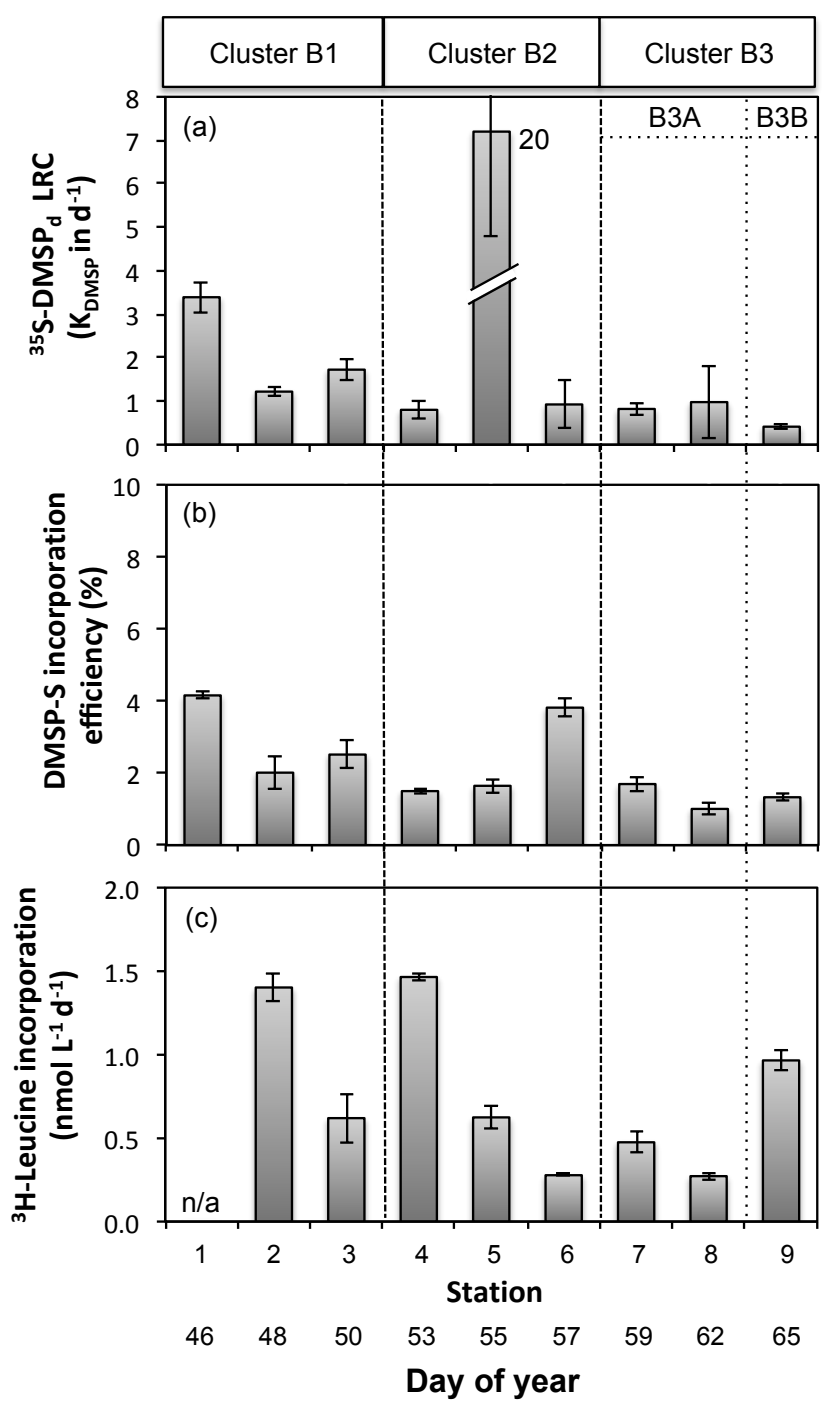

Figure 3. (a) Microbial $\mathrm{DMSP}_{\mathrm{d}}$ loss rate constant $\left(k_{\mathrm{DMSP}_{\mathrm{d}}}\right.$ in day $^{-1}$ ); (b) microbial assimilation efficiency of DMSP-S into macromolecules (\%); (c) microbial ${ }^{3} \mathrm{H}$-leucine incorporation $\left(\mathrm{nmol} \mathrm{L}{ }^{-1} \mathrm{day}^{-1}\right)$ at nine stations during the SOAP voyage in February and March 2012. The three sampling clusters are noted as B1, B2, and B3. Stacks and error bars indicate mean and standard deviation of triplicate samples. NA indicates data that are not available.

measured in sampling cluster B1 with concentrations varying between 4.9 and $14.5 \mathrm{nmolDMS} \mathrm{L}^{-1}$. Stations 4 to 6 , within the most easterly of the sampling clusters (B2), had DMS concentrations ranging from 1 to $6.9 \mathrm{nmol} \mathrm{L}^{-1}$, while stations 7-9 in B3 had a range of DMS concentrations from 4.8 to $10.5 \mathrm{nmol} \mathrm{L}^{-1}$.

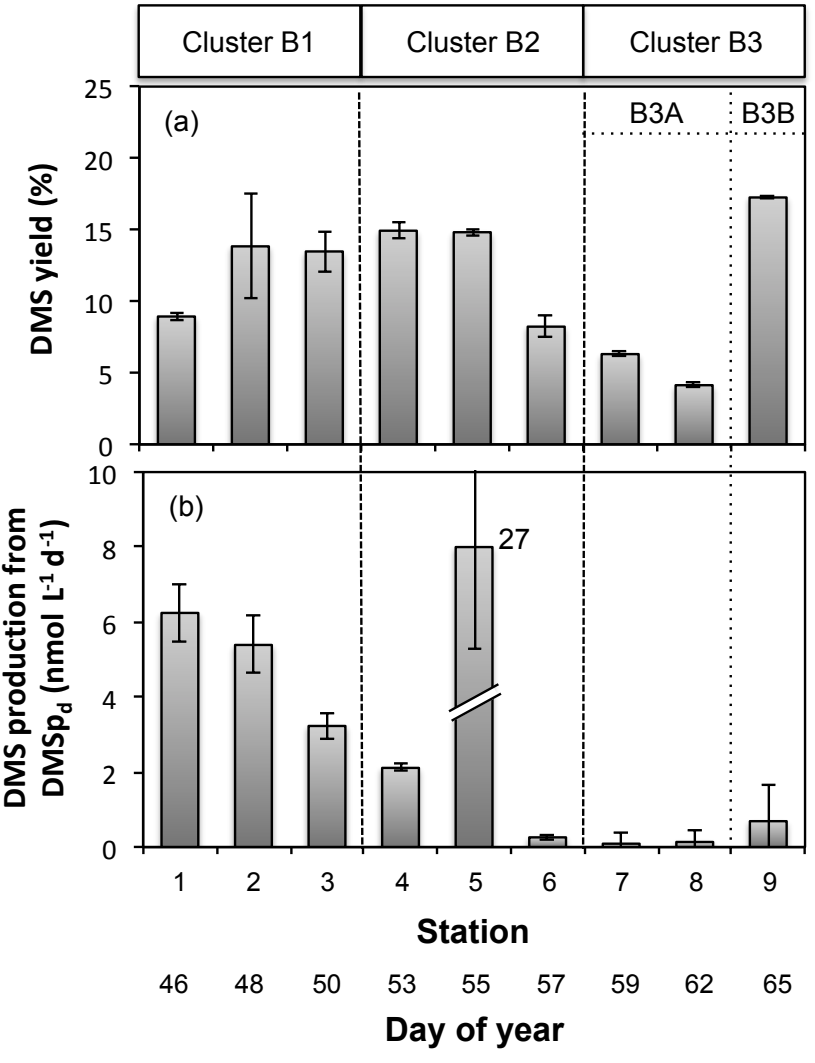

Figure 4. (a) Microbial DMS yields (\%) and (b) gross DMS production from $\mathrm{DMSP}_{\mathrm{d}}\left(\mathrm{nmol} \mathrm{L}^{-1} \mathrm{day}^{-1}\right)$ at nine stations during the SOAP voyage in February and March 2012. The three distinct sampling clusters are noted as B1, B2, and B3. Stacks and error bars indicate mean and standard deviation of triplicate samples.

\subsection{Microbial uptake and transformation of sulfur compounds}

The ${ }^{35} \mathrm{~S}-\mathrm{DMSP}_{\mathrm{d}}$ loss rate constant $\left(k_{\mathrm{DMSP}_{\mathrm{d}}}\right.$; Fig. 3a) varied between 0.4 and $3.4 \mathrm{day}^{-1}$, with the exception of a higher value of $19.9 \mathrm{day}^{-1}$ measured in the B2 cluster at station 5. The sulfur assimilatory metabolism of ${ }^{35} \mathrm{~S}_{-} \mathrm{DMSP}_{\mathrm{d}}$, expressed as the percentage of ${ }^{35} \mathrm{~S}^{-D_{M S S P}}$ incorporated into macromolecules (Fig. 3b), ranged from 1 to $4.2 \%$ across all stations. Rates of bacterial carbon production, measured as the incorporation of ${ }^{3} \mathrm{H}$-leucine into macromolecules, showed 5-fold variability throughout the three sampling clusters, ranging from 0.27 to $1.46 \mathrm{nmol} \mathrm{C} \mathrm{L}^{-1} \mathrm{day}^{-1}$.

Yields of DMS from dissolved DMSP, determined as the fraction of consumed $\mathrm{DMSP}_{\mathrm{d}}$ converted into DMS, ranged from 4 to $17 \%$ (Fig. 4a), with lowest and highest yields found within the same cluster (B3) at stations 8 and 9, respectively. The average DMS yield in clusters B1 and B2 were very similar at 12.1 and $12.7 \%$, respectively. The production of DMS from $\mathrm{DMSP}_{\mathrm{d}}$, determined as the product of DMS yields and $\mathrm{DMSP}_{\mathrm{d}}$ consumption rates, varied by more than 2 orders of magnitude across the sampling area 
(Fig. 4b). Lowest DMS production rates from $\mathrm{DMSP}_{\mathrm{d}}$ were measured in the third sampling cluster (B3) where values remained below $0.7 \mathrm{nmol} \mathrm{L}^{-1}$ day $^{-1}$. A wide-ranging set of DMS production from DMSP $_{d}$ was estimated within $\mathrm{B} 2$ with 0.25 to $27 \mathrm{nmol} \mathrm{L}^{-1}$ day $^{-1}$. Variability of DMS production from $\mathrm{DMSP}_{\mathrm{d}}$ within cluster $\mathrm{B} 1$ was lower, with rates varying between 3.2 and $6.2 \mathrm{nmol} \mathrm{L}^{-1} \mathrm{day}^{-1}$.

\section{Discussion}

\subsection{Bloom dynamics in the subtropical front}

The subtropical convergence region under study was characterized by overall high-standing stocks of both autotrophic biomass (proxied by phytoplankton $\mathrm{C}$ and $\mathrm{Chl} a$ ) and biogenic sulfur compounds (Table 1; Fig. 2a-c). The frontal zone over Chatham Rise is known for its high productivity (Bradford-Grieve et al., 1997; Sutton, 2001), fostering extensive phytoplankton blooms visible from space (Sadeghi et al., 2012). Plankton bloom dynamics are known to play a crucial role in influencing reservoirs and driving fluxes of biogenic DMSP and DMS (Simó, 2001; Stefels et al., 2007). As evidenced by the patterns in nutrients and $\mathrm{Chl} a$, the cruise track crossed paths with blooms in various developmental stages in contrasting water masses. Overall quasi-depletion of silicate standing stocks was evident from the $<0.6 \mu \mathrm{mol} \mathrm{L}{ }^{-1}$ values detected in all stations investigated in the study region (except for station 6 with $1.2 \mu \mathrm{mol}$ silicate $\mathrm{L}^{-1}$ ). Nitrate concentrations found in B1 and B3 averaged 5.2 $\pm 1.7 \mu \mathrm{mol} \mathrm{L}{ }^{-1}$ and $3.6 \pm 1.5 \mu \mathrm{mol} \mathrm{L}^{-1}$, respectively. These nutrient signatures are a common feature of subantarctic waters to the south of the STF displaying depletion of silicates relative to nitrate (Sarmiento et al., 2004). Concentrations of Chl $a$ in $\mathrm{B} 1$ (mean $1.1 \pm 0.3 \mu \mathrm{g} \mathrm{L}^{-1}$ ) were found to be higher than a threshold concentration of $0.7 \mu \mathrm{g} \mathrm{L}^{-1}$ used as a criterion to distinguish regions of local biomass enrichment at the subtropical convergence (Llido et al. 2005). These results coupled to the high regional phytoplankton-associated $\mathrm{C}$ biomass $\left(61 \mu \mathrm{g} \mathrm{L}^{-1}\right)$ and the low regional $p \mathrm{CO}_{2}$ minimum

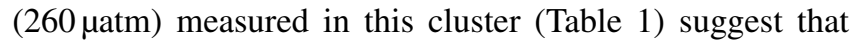
B1 was productive and fuelled by ample nitrate reservoirs at the time of sampling. After being away for 7 days, the cruise track returned to the subantarctic-type waters near B1 on 28 February to sample the B3 cluster stations. At that time, the physicochemical and biological signatures in B3 (stations 7-9) differed slightly from those of B1 and displayed higher regional $p \mathrm{CO}_{2}$ minimum (305 $\left.\mu \mathrm{atm}\right)$, 2-fold lower mean phytoplankton $\mathrm{C}$ biomass $\left(28 \mu \mathrm{g} \mathrm{L}^{-1}\right)$, and lower Chl $a$ concentrations at stations 7 and $8\left(0.4 \mu \mathrm{gL}^{-1}\right)$ but comparable concentrations at station $9\left(1 \mu \mathrm{g} \mathrm{L}^{-1}\right)$. Overall, these results suggest that phytoplankton biomass was lower in response to lower nutrient reservoirs and possibly greater grazing pressure in B3, although specific information on zooplankton activity is not available.
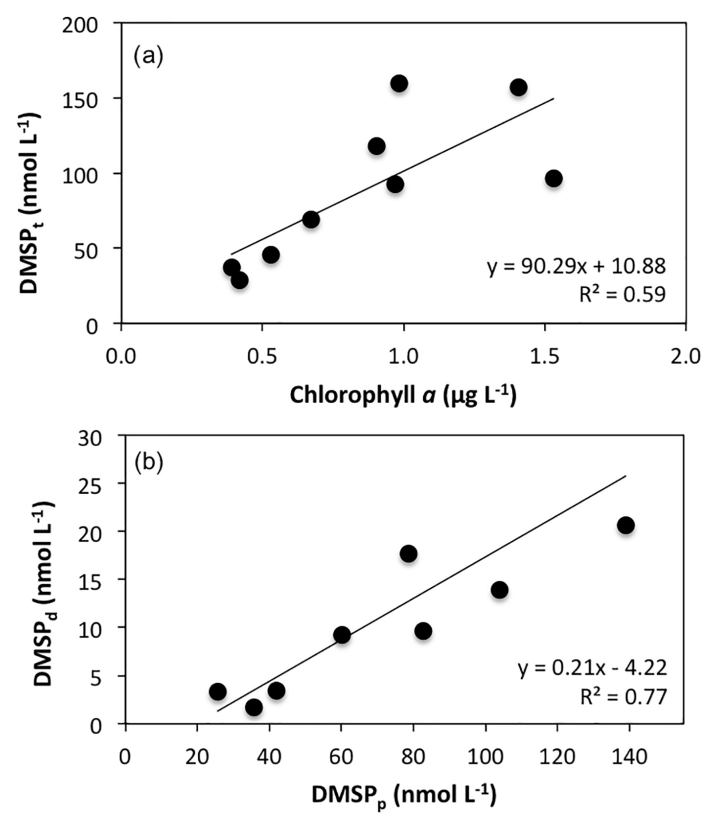

Figure 5. Model II regressions between (a) concentrations of Chl $a$ and $\mathrm{DMSP}_{\mathrm{t}}$; (b) concentrations of $\mathrm{DMSP}_{\mathrm{p}}$ and $\mathrm{DMSP}_{\mathrm{d}}$.

The second cluster of stations (B2) was geographically distant from the two others (B1 and B3; Fig. 1b) and had characteristics of slightly warmer subtropical waters (Table 1). Regionally, this study area displayed the highest $p \mathrm{CO}_{2}$ but had similar mean phytoplankton-associated $\mathrm{C}$ biomass $\left(32 \mu \mathrm{gL}^{-1}\right)$ to B3. Regional maximum Chl $a$ (max of $1.5 \mu \mathrm{g} \mathrm{L}^{-1}$ ) and nitrate levels (cluster average of $0.5 \pm 0.7 \mu \mathrm{mol} \mathrm{L}{ }^{-1}$ ) were the lowest among the blooms investigated. These low nutrient features are thought to be typical of subtropical waters north of the subtropical front which are also known to display stronger vertical stratification (Llido et al., 2005). Small-celled phytoplankton $(<5 \mu \mathrm{m})$ are known to typically develop blooms that exhibit low Chl $a$ concentrations ( $<2 \mu \mathrm{g} \mathrm{L}^{-1}$; Holligan et al., 1993). Such is the case for the common and globally dominant bloomforming coccolithophore Emiliania huxleyi (Paasche, 2001), that typically has low intracellular levels of Chl $a(<0.4 \mathrm{pg}$ Chl $a$ per cell; Daniels et al., 2014), and which dominated the community (Law et al., 2017) during this study.

\subsection{Relating bloom dynamics with concentrations of reduced $S$ compounds}

Despite differences in phytoplankton dominance within blooms (Table 1), pools of $\mathrm{DMSP}_{\mathrm{t}}$ measured in this study showed a strong association with overall phytoplankton biomass as suggested by the positive correlation observed between DMSP $\mathrm{t}_{\mathrm{t}}$ and Chl $a\left(r_{\mathrm{s}}=0.83, p<0.01, n=9\right.$; Table 2). A Model II linear regression model suggests that $59 \%$ of the variance in pools of $\mathrm{DMSP}_{\mathrm{t}}$ can be explained by the variability in stocks of Chl $a$ (Fig. 5a), while the correlation 
Table 2. Spearman's rank correlation coefficients $\left(r_{\mathrm{s}}\right)$ for various variables measured during SOAP.

\begin{tabular}{|c|c|c|}
\hline \multicolumn{2}{|l|}{ Variables } & \multirow{2}{*}{$\begin{array}{l}r_{\mathrm{s}} \text { coefficient } \\
0.83^{* *}\end{array}$} \\
\hline Chl $a$ & $\mathrm{DMSP}_{\mathrm{t}}$ & \\
\hline $\operatorname{DMSP}_{\mathrm{p}}$ & $\mathrm{DMSP}_{\mathrm{d}}$ & $0.92^{* * *}$ \\
\hline Leucine incorporation & $\mathrm{DMSP}_{\mathrm{d}}$ & $0.86^{* *}$ \\
\hline Leucine incorporation & DMS yield & $0.84^{* *}$ \\
\hline
\end{tabular}

*** $p<0.001$ and ${ }^{* *} p<0.01 ; n=9$ for all variables except for leucine incorporation, where $n=8$.

between DMSP $_{\mathrm{p}}$ and Chl $a$ is of similar strength $\left(r^{2}=0.57\right.$; data not shown). Establishing a strong relationship between DMSP and phytoplankton biomass has been historically met with limited success (Bürgermeister et al., 1990; Townsend and Keller, 1996; Turner et al., 1988). The main reason for this is that concentrations of DMSP are generally related to the presence of specific DMSP-rich phytoplankton species rather than to overall phytoplankton biomass, which is often dominated by large DMSP-poor diatoms (Lizotte et al., 2012; Stefels et al., 2007). In this study, concentrations of DMSP co-varied significantly with phytoplankton biomass because of the persistent dominance of dinoflagellates and coccolithophores, both DMSP-rich taxa, within the three blooms investigated.

Unlike the strong correlation found with $\mathrm{DMSP}_{\mathrm{t}}$, no significant relationships were detected between DMS and phytoplankton biomass $(\mathrm{Chl} a$ ) in our study, as reported in Bell et al. (2015). The lack of strong relationship between DMS and Chl $a$ is likely due to many biological and physical processes involved in its production and overturning (Dacey et al., 1998; Van Duyl et al., 1998; Kettle et al., 1999; Kwint and Kramer, 1996; Leck et al., 1990; Scarratt et al., 2002; Simó and Pedrós-Alió, 1999; Stefels et al., 1995; Steinke et al., 2000; Turner et al., 1988). Several studies have established links between environmental forcings, such as the surface mixed layer depth and the irradiance regime, and their role in driving surface DMS concentrations (Lana et al., 2012; Lizotte et al., 2012; Miles et al., 2009, 2012; Vallina and Simó, 2007). The associations between DMS and MLD as well as between DMS and daily-averaged irradiance were not found to be statistically significant within the limited dataset available in this study ( $p=0.86$ and $p=0.54$, respectively). SRD standardized over MLD was not found to improve the significance of the association between DMS and irradiance regime. Because the spectral attenuation of solar radiation in oceanic waters varies rapidly with depth and in association with the constituents within seawater (Doron et al., 2007), it cannot be excluded that differences in sampling depth (sipper versus Niskin) may have obscured links between DMS and light. Heterogeneity in sampling times (Table 1) could also have resulted in differences in light history experienced by the DMS-producing communities. Nonetheless, DMS reservoirs and those of its precursor (DMSP) were found to be abundant in the three blooming clusters as discussed in the next section.

\subsection{High concentrations of $S$ compounds in subtropical frontal surface waters}

In this study, concentrations of $\mathrm{DMSP}_{\mathrm{t}}$ reached 110 to $160 \mathrm{nmol} \mathrm{L}^{-1}$ in the first cluster, in association with a bloom characterized by elevated concentrations of DMS (regionally up to $20 \mathrm{nmol} \mathrm{L}^{-1}$ ) and dominated by dinoflagellates, a diverse phytoplankton group known for its prolific DMSP producers (Belviso et al., 1990; Keller, 1989; Turner et al., 1988). Few comparative DMSP datasets are available for waters near New Zealand; however, the current $\mathrm{DMSP}_{\mathrm{t}}$ concentrations are 2-3 times higher than the highest DMSP value $\left(52 \mathrm{nmol} \mathrm{L}^{-1}\right)$ reported for three open-water transects conducted between 49 and $76^{\circ} \mathrm{S}$ latitude within the New Zealand sector of the Southern Ocean during austral spring (Kiene et al., 2007). Species of Gymnodinium spp., the dominant dinoflagellate taxon in B1, have been found to contain potentially high cytosolic DMSP (up to 244 pg DMSP/cell; Keller, 1989) that could have significantly contributed to the elevated reservoirs of $\mathrm{DMSP}_{\mathrm{t}}$ observed in these subantarctictype waters. A previous study conducted in waters of the subtropical convergence zone $\left(40-45^{\circ} \mathrm{S}\right)$ south of Australia had demonstrated a link between relatively high concentrations of DMSP (up to $55 \mathrm{nmol} \mathrm{L}^{-1}$ ) and dinoflagellate biomass as well as a link with low microzooplankton grazing rates (Jones et al., 1998). Gaps in the specific information concerning dinoflagellate abundance in our sampling stations (Table 1) prevented any attempt at relating this DMSP-rich group to overall in situ DMSP concentrations.

The second bloom investigated was dominated by coccolithophores and had $\mathrm{DMSP}_{\mathrm{t}}$ concentrations ranging from 45 to $96 \mathrm{nmol} \mathrm{L}^{-1}$ at stations 4 to 6 . Emiliania huxleyi, a species exhibiting high intracellular DMSP (Franklin et al., 2010; Liu et al., 2014) and the dominant coccolithophore in this study (Law et al., 2017), has been shown to represent a major component of extensive coccolithophore blooms in New Zealand's coastal waters (Chang and Northcote, 2016; Rhodes et al., 1994). Maximal coccolithophore cell densities (up to $21.1 \times 10^{6}$ cells $\mathrm{L}^{-1}$ ) reached in the second bloom are 4- to 5-fold higher than maximal cell densities reached in coccolithophore blooms in the North Atlantic during summer: maximum of $5.5 \times 10^{6}$ cells $\mathrm{L}^{-1}$ (Matrai and Keller, 1993) and maximum of $4.0 \times 10^{6}$ cells $\mathrm{L}^{-1}$ (Malin et al., 1993), and associated with very high levels of $\mathrm{DMSP}_{t}$ $\left(>400 \mathrm{nmol} \mathrm{L}^{-1}\right)$. While the $\mathrm{DMSP}_{\mathrm{t}}$ concentrations were high in B2, even higher concentrations might have been expected given the high coccolithophore cell abundances. Variations in cell-specific DMSP quotas, nutrient, and physiological statuses of the phytoplankton communities, as well as grazing pressure (Stefels et al., 2007) could explain these differences. Emiliania huxleyi is found to dominate phytoplankton community composition in both bloom and non-bloom 
conditions in this STF region (Chang and Northcote, 2016), suggesting that these relatively high summer DMSP features could extend over a larger region which encircles the entire Southern Ocean during austral summer in a band dubbed the "Great Calcite Belt" (Balch et al., 2011).

The third and last bloom sampled (B3) was characterized by a mixed phytoplankton population with high abundances of both dinoflagellates and coccolithophores. Although no data for coccolithophore abundance were available at station 9, samples collected in surface waters the day before (4 March) displayed coccolithophore abundance of $20.3 \times 10^{6}$ cells L $^{-1}$ suggesting a transition towards a coccolithophore-dominated assemblage at the end of the sampling period. Concentrations of $\mathrm{DMSP}_{t}$ (29-37 nmol L$\left.{ }^{-1}\right)$ were lower at stations $7-8$ and increased to $93 \mathrm{nmol} \mathrm{L}^{-1}$ at station 9, likely reflecting this phytoplankton community shift. Pools of particulate DMSP $\left(\mathrm{DMSP}_{\mathrm{p}}=\mathrm{DMSP}_{\mathrm{t}}-\mathrm{DMSP}_{\mathrm{d}}\right)$ ranged from 26 to $83 \mathrm{nmol} \mathrm{L}^{-1}$ in cluster B3 and were similar to measurements of DMSP $_{\mathrm{p}}$ (28 to $40 \mathrm{nmol} \mathrm{L}^{-1}$ ) made in waters surrounding an iron enrichment patch during the SAGE experiment conducted in subantarctic waters southeast of New Zealand during the months of March and April (Archer et al., 2011). These results suggest that relatively high concentrations of DMSP may persist in the STF zone well into the autumnal season, which begins in mid-March in the Southern Hemisphere.

Cluster averages of DMS concentrations in this study were higher than historical data represented in the latest DMS climatologies for the NEWZ province $\left(<3 \mathrm{nmol} \mathrm{L}^{-1}, n=6\right.$; Lana et al., 2011). Clusters B1, B2, and B3 displayed average ( $n=3$ for each cluster) near-surface concentrations of $9.5 \pm 4.8,3.6 \pm 3.0$, and $7.0 \pm 3.1 \mathrm{nmol} \mathrm{DMS} \mathrm{L}^{-1}$, respectively (Fig. 2c). These results underscore the fact that coverage in the previous climatological data likely did not capture all the productive hydrographic and seasonal features of this region. While many studies have reported on Chl $a$ enhancement across frontal regions of the oceans, only a few studies have described regional increases in DMS associated with frontal waters (Holligan et al., 1987; Matrai et al., 1996), and these studies have provided only limited information on DMSP. Results from the current study thus provide much-needed information on the distribution of DMS but also DMSP in a critically under-sampled area of the global ocean, and they highlight the importance of oceanic fronts as hotspots for biogenic sulfur compounds.

Finally, an important portion of the total sea surface pools of DMSP were found as dissolved material in this study, with 5 to $21 \%$ of $\mathrm{DMSP}_{\mathrm{t}}$ prevailing as $\mathrm{DMSP}_{\mathrm{d}}$ across the three distinct clusters of the study region (Fig. 2b). Overall in situ $\mathrm{DMSP}_{\mathrm{d}}$ concentrations ranged from 2 to $32 \mathrm{nmol} \mathrm{L}^{-1}$, with highest concentrations being 1 order of magnitude higher than the maximum DMSP $_{\mathrm{d}}$ concentration of $2.8 \mathrm{nmol} \mathrm{L}^{-1}$ found using the same SVDF procedure by Kiene and Slezak (2006) over wide-ranging ocean water types. By examining the linear relationship between concentrations of $\mathrm{DMSP}_{\mathrm{p}}\left(\mathrm{DMSP}_{\mathrm{p}}\right.$ determined as $\left.\mathrm{DMSP}_{\mathrm{t}}-\mathrm{DMSP}_{\mathrm{d}}\right)$ and those of $\mathrm{DMSP}_{\mathrm{d}}$ (Fig. 5b), we are able to show that the slope $(0.21)$ of the Model II regression analysis is very similar to the slope (0.20) obtained by Kiene and Slezak (2006) for SVDF DMSP $_{d}$ samples from the Sargasso Sea. Although it is impossible to entirely circumvent bottle, filtration, and/or processing effects that could lead to overestimation of $\mathrm{DMSP}_{\mathrm{d}}$ concentrations, despite careful handling, it is nonetheless noteworthy that, despite large contrasts in trophic status, our results show a tendency for $\mathrm{DMSP}_{\mathrm{d}}$ to build up in surface waters in proportion to its particulate counterpart, constituting up to $21 \%$ of the total DMSP pool in our study. The fuelling of dissolved DMSP reservoirs in the water column has biogeochemical importance considering this compound supplies heterotrophic microorganisms with $\mathrm{C}$ and $\mathrm{S}$ as is discussed in the next section.

\subsection{Cycling of S compounds through heterotrophic bacterioplankton}

\subsubsection{Wide-ranging microbial DMSP $_{d}$ rate constants}

To our knowledge, this study provides the first DMSP process rate measurements across a frontal zone, within three quasi-co-occurring but distinct phytoplankton blooms. Except for station 5, which will be discussed below, $\mathrm{DMSP}_{\mathrm{d}}$ loss rate constants $\left(k_{\mathrm{DMSP}_{\mathrm{d}}}\right)$ varied between 0.4 and 3.4 day $^{-1}$, suggesting wide-ranging turnover times of DMSP $_{d}$ reservoirs, between approximately $7 \mathrm{~h}$ and 2.5 days (Fig. 3a). Assuming steady-state conditions, these turnover times imply that between 2 and $14 \%$ of the DMSP stock was renewed hourly by autolysis, exudation viral attack, and grazing (Stefels et al., 2007). These results are comparable with similar ranges of $k_{\mathrm{DMSP}_{\mathrm{d}}}$ measurements conducted in various oceanic environments (Table 3). Our highest value of $k_{\mathrm{DMSP}_{\mathrm{d}}}\left(19.9 \mathrm{day}^{-1}\right)$ was recorded at station 5, within B2. High $k_{\mathrm{DMSP}_{\mathrm{d}}}$ values are not commonly reported in the literature except for the $22.1 \mathrm{day}^{-1}$ observed by Royer et al. (2010) in the northeast Pacific, which was similar to our highest rate. These very rapid turnover times (about $1 \mathrm{~h}$ at station 5) could reflect transient periods of increased bacterial abundance or production. In situ rates of leucine incorporation by bacteria were not particularly high at station 5 (0.62 compared to an overall range of 0.27 to $1.46 \mathrm{nmol} \mathrm{L}^{-1} \mathrm{day}^{-1}$ ), nor was the abundance of heterotrophic bacterial cells $(0.85$ at station 5 , range of 0.34 to $1.19 \times 10^{9}$ cells $\mathrm{L}^{-1}$ ) and the concentration of $\mathrm{DMSP}_{\mathrm{d}}$ (nine compared to a global range of 2 to $32 \mathrm{nmol} \mathrm{L}^{-1}$ ). Furthermore, in our study, no overall significant trends were detected between $\mathrm{DMSP}_{\mathrm{d}}$ loss rate constants $\left(k_{\mathrm{DMSP}_{\mathrm{d}}}\right)$ and numbers of bacteria or rates of leucine incorporation. It has been suggested that loss rate constants of DMSP $_{d}$, rather than being directly related to stocks of bacteria, could be more related to bacterial community composi- 


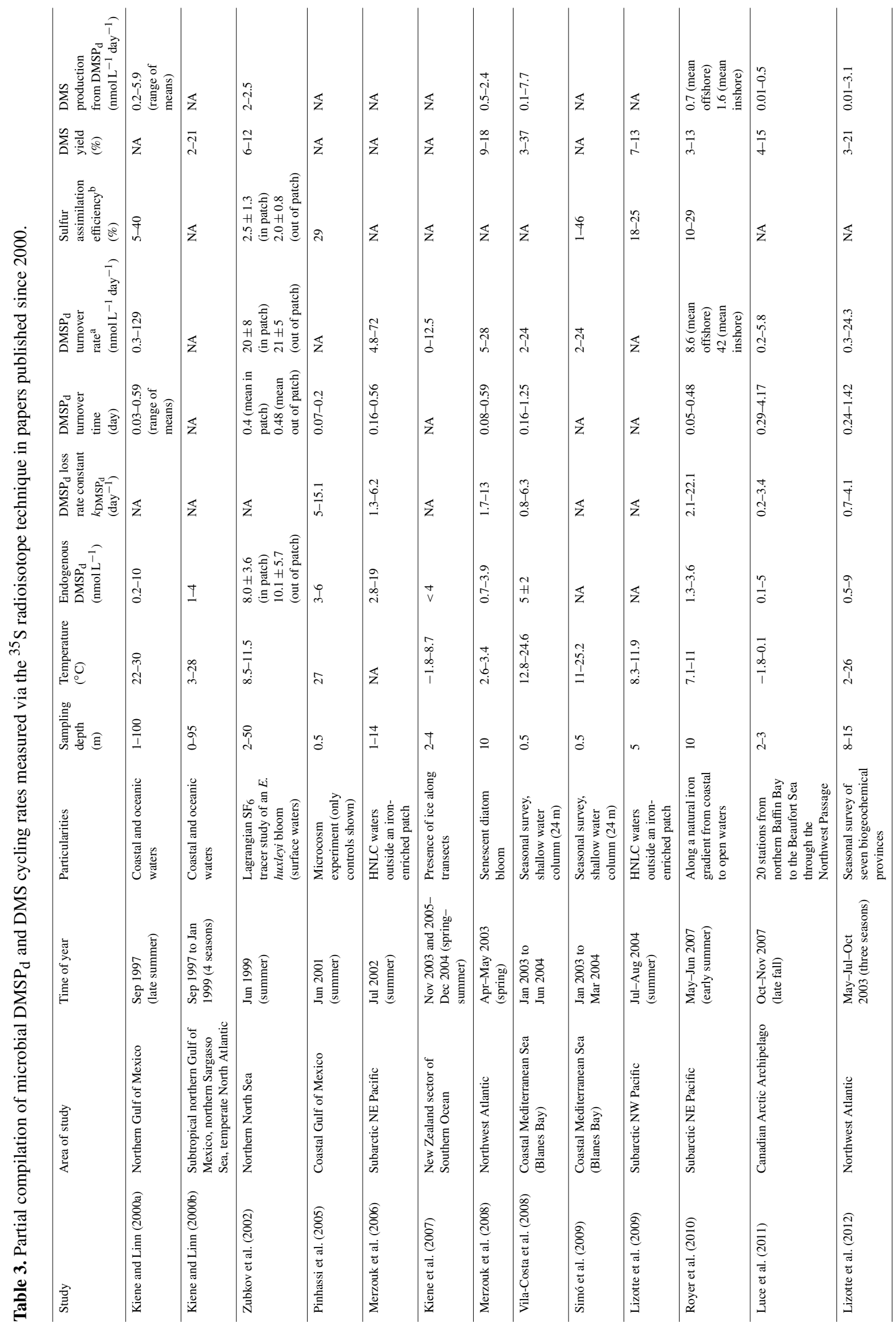




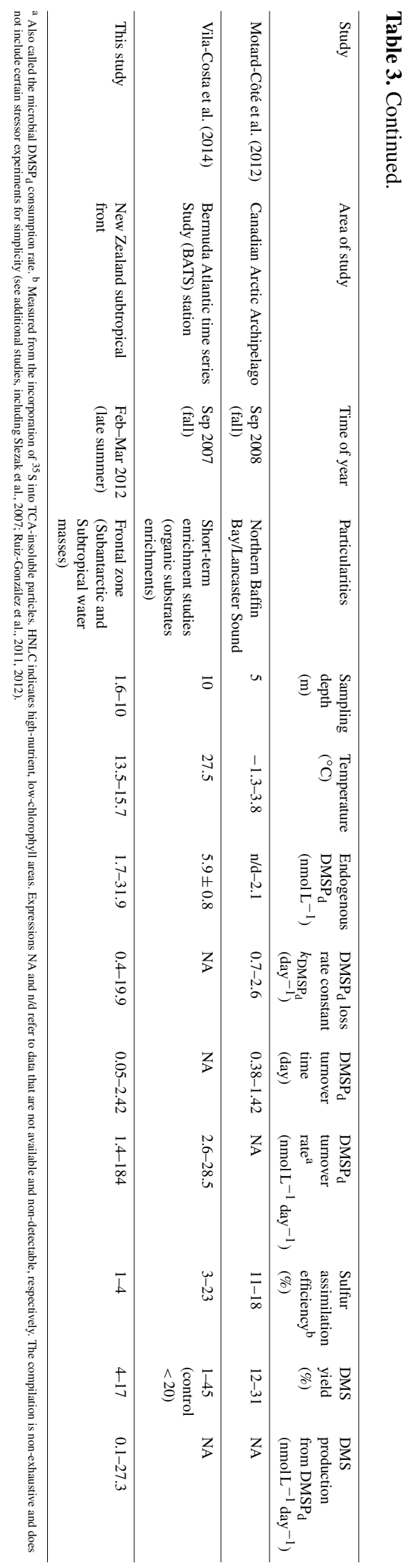

tion, and particularly to certain members of Alphaproteobacteria, Gammaproteobacteria, and cyanobacteria, that could all potentially represent significant contributors to DMSP metabolism (Malmstrom et al., 2004a, b, 2005; Royer et al., 2010; Vila-Costa et al., 2007; Vila et al., 2004). On the whole, microbial $\mathrm{DMSP}_{\mathrm{d}}$ rate constants were variable within the study region (50-fold range), with no specific responses related to the presence of diverging phytoplankton assemblages and biological characteristics within blooms.

\subsubsection{Fulfilled bacterial sulfur requirements in a sulfur-rich environment}

The assimilatory metabolism of sulfur from DMSP is a key control on the amount of this compound diverted away from DMS. Assimilation efficiency of sulfur from ${ }^{35}{ }^{3}-$ DMSP $_{d}$ into bacterial macromolecules was low $(<5 \%)$ throughout the study region (Fig. 3b). Values reported in this study are below a relatively narrow range of DMSP-S assimilation efficiency values reported in various studies (see Table 3). Taking into account the DMSP-S incorporation efficiency, the potential contribution of DMSP-S to bacterial sulfur biomass production was estimated from bacterial $\mathrm{C}$ production and lower and upper limits of bacterial C:S molar ratios (32 to 248 from Cuhel and Taylor, 1981; Fagerbakke et al., 1996). For all the reported C:S values, calculated DMSP-S incorporation exceeded $100 \%$ of bacterial sulfur biomass production estimates (data not shown), suggesting that DMSP availability was in excess of bacterial sulfur requirements. These results agree with several studies (Kiene and Linn, 2000b; Simó et al., 2009; Vila-Costa et al., 2007, 2014) suggesting that DMSP acts as a major source of $\mathrm{S}$ for heterotrophic bacterioplankton. A possible caveat of these estimates is the fact that DMSP-S assimilation may also include assimilation by cyanobacteria and phytoplankton (Malmstrom et al., 2005; Vila-Costa et al., 2006a), which likely do not contribute to leucine incorporation. This would lead to overestimation of the contribution of DMSP to bacterial S production. Overall, and assuming that heterotrophic bacteria dominate the uptake of DMSP, the S assimilation efficiencies $(<5 \%)$ measured in this study point towards a rapid saturation of $S$ requirements by the microbial assemblages in DMSP-rich waters of the subtropical front.

\subsubsection{Microbial DMS yield and gross production of DMS from DMSP $_{d}$}

Microbial DMS yields, the conversion efficiency of DMSP into DMS, varied from 4 to $17 \%$ with an overall average of $11 \%$ across the entire study region, irrespective of water mass provenance and bloom association (Fig. 4a). Our results add to the mounting evidence that, as a whole, the span in endogenous proportions of $\mathrm{DMSP}_{\mathrm{d}}$ consumed by bacteria and cleaved into DMS is similar across various oceanic environments (see Table 3). A significant and positive rela- 
tionship was found between rates of bacterial leucine incorporation and DMS yields in this study $\left(r_{\mathrm{s}}=0.84, p<0.01\right.$, $n=8)$. This relationship suggests that as carbon incorporation for protein synthesis was heightened in the microbial communities, the proportional use of DMSP as a carbon source also increased, leading to higher $\mathrm{DMSP}_{\mathrm{d}}$-to-DMS conversion efficiencies (Table 2). Furthermore, prokaryotic protein synthesis, estimated by the bacterial incorporation of leucine (Kirchman et al., 1985), appeared to be significantly associated with the supply of $\mathrm{DMSP}_{\mathrm{d}}$ in this study $\left(r_{\mathrm{S}}=0.86, p<0.01, n=8\right.$; Table 2$)$. With greater bacterial production rates of $\mathrm{C}$, it is likely that bacterial production of $\mathrm{S}$ was also heightened in this study with potential modifications in assimilation efficiency of $\mathrm{S}$ from consumed ${ }^{35} \mathrm{~S}$ DMSP. A trend of increasing ${ }^{35} \mathrm{~S}$-DMSP assimilation yields concomitant with increased leucine incorporation rates was seen (data not shown) but the lack of statistical significance limits further interpretation of this tendency. The overall low proportion of ${ }^{35} \mathrm{~S}$-DMSP consumed and assimilated into macromolecules combined with the potentially rapid saturation of $\mathrm{S}$ requirements by the microbial assemblages, discussed previously, suggests that heterotrophic bacteria may have had access to ample sources of sulfur, including nonlabelled in situ DMSP $P_{\mathrm{d}}$. High concentrations of both in situ

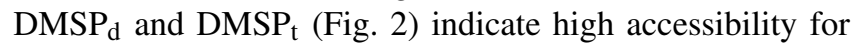
free-living (FL) bacteria of these methylated $\mathrm{S}$ compounds directly in the water column but also potentially for particleassociated (PA) bacteria in microzones surrounding phytoplankton cells and detrital particles such as faecal pellets and marine snow (see review by Ramanan et al., 2016). These phycospheres and other microzones of enhanced gradients of dissolved organic matter (Amin et al., 2015; Bell and Mitchell, 1972; Simon et al., 2002) are often associated with populations of bacteria that are distinct from the surrounding open habitat, that can vary according to phytoplankton community composition (Cooper and Smith, 2015, Rieck et al., 2015), and that may possess higher uptake kinetics for sub-

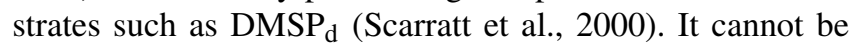
excluded that such PA bacterioplankton were present in our experiment, in association with the DMSP-rich phytoplankton groups identified, leading to overall low $\mathrm{S}$ assimilation efficiencies from consumed ${ }^{35} \mathrm{~S}^{-\mathrm{DMSP}_{\mathrm{d}}}$ despite changes in bacterial $\mathrm{C}$ production. This idea is supported by conclusions from Scarratt et al. (2000) suggesting that PA bacteria can "afford" to make use of DMSP simply as a C source because their $S$ requirements are amply satisfied.

The fate of S in DMSP-metabolizing bacterial communities is complex and most likely affected by numerous factors, at least one of which is the $\mathrm{S}$ requirement relative to the availability of organic S. Findings from this study are consistent with the hypothesis that organic $S$ in excess of bacterial requirements biases DMSP metabolism against demethylation (Kiene et al., 2000; Levasseur et al., 1996; Pinhassi et al., 2005). These observations agree with results from Lizotte et al. (2009) who observed an increase in DMS yields follow- ing the addition of non-limiting concentrations of $\mathrm{DMSP}_{\mathrm{d}}$ and increases in microbial incorporation of leucine during an ocean iron fertilization experiment in the subarctic Pacific. Furthermore, at a physiological level, factors including bacterial carbon requirements and concentrations of DMSP degradation products can also exert an impact on the fate of DMSP (Kiene et al., 2000). Since the radioisotope technique used to examine the microbial cycling of $\mathrm{DMSP}_{\mathrm{d}}$ traces only the S moiety, significant respiration of C-DMSP can occur (Vila-Costa et al., 2010). As such, the combination of rather typical $\mathrm{DMSP}_{\mathrm{d}}$ turnover times (overall average of $<1$ day) and low DMSP-S assimilation efficiencies $(<5 \%)$ could be an indication of the availability of $\mathrm{C}$ - and $\mathrm{S}$-rich compounds, including DMSP, to the bacterial assemblages in this study.

Regardless of the positive associations between bacterial carbon production and the supply of $\mathrm{DMSP}_{\mathrm{d}}$, as well as DMSP $_{d}$ conversion efficiency into DMS, yields of DMS never exceeded $17 \%$. Altogether, our results reinforce the concept that DMSP-to-DMS conversion is not the main fate of microbial DMSP $_{d}$ turnover in natural environments (see reviews by Simó, 2001 and Stefels et al., 2007), never exceeding $37 \%$ of consumed DMSP $_{\mathrm{d}}$ in most ${ }^{35} \mathrm{~S}$-DMSP tracer studies (see compilation in Table 3). However, even modest variance in DMSP $_{\mathrm{d}}$-to-DMS conversion efficiencies can result in considerable variations in the production rate of DMS in sea surface waters. In this study, gross DMS production from $\mathrm{DMSP}_{\mathrm{d}}$ ranged from near detection limits to a high of $27 \mathrm{nmol}$ of DMS per litre per day (Fig. 4b). This high rate reflects the very high $\mathrm{DMSP}_{\mathrm{d}}$ scavenging by the bacteria measured on this particular day coupled to high DMSP $_{\mathrm{d}}$-to-DMS conversion efficiency at station 5 (Figs. 3a and $4 \mathrm{a}$ ). The fact that concentrations of DMS remained low $\left(3 \mathrm{nmol} \mathrm{L}^{-1}\right)$ suggests that potential sinks, particularly bacterial DMS consumption, but not excluding DMS photooxidation and ventilation (Table 1), may have kept this pool in check. Omitting this very high rate measured on 24 February, DMS production from $\mathrm{DMSP}_{\mathrm{d}}$ contributed on average $2.3 \mathrm{nmol} \mathrm{L}^{-1} \mathrm{day}^{-1}$ of DMS to near-surface reservoirs (ranging from 0.07 to $6.2 \mathrm{nmolDMS} \mathrm{L}^{-1} \mathrm{day}^{-1}$ ) of the study region. These values are comparable to DMS production rates from $\mathrm{DMSP}_{\mathrm{d}}$ previously reported (Table 3 ). It is noteworthy that although production rates of DMS from $\mathrm{DMSP}_{\mathrm{d}}$ were low in B3, concentrations of DMS remained high despite slightly higher wind speeds during this period of sampling (see Bell et al., 2015), which should have enhanced ventilation of DMS to the atmosphere. This suggests that sinks for DMS were somehow alleviated, for example, through (1) a decrease in photo-oxidation of DMS related to a reduction in irradiance fields and a deepening of the mixed layer (see Table 1); (2) a reduction in bacterial consumption of DMS, for which unfortunately no specific information is available but that could be associated with a decrease in bacterial abundance (Table 1).

Alternatively, but not excluding these potential sinks, other sources of DMS (non-bacterial) are likely to have contributed 
to the concentrations of DMS. Assuming steady-state conditions, the comparison between our microbially mediated DMS production rates and the concentrations of DMS in near-surface waters suggests that bacteria alone could not have sustained the DMS pool at most stations and particularly in B3. Average calculated DMS turnover times due to production from $\mathrm{DMSP}_{\mathrm{d}}$ were similar between $\mathrm{B} 1$ (2.3 days) and B2 (2.4 days) but increased to an average 36.5 days in B3. Considering that DMS sinks commonly proceed on timescales of hours to a few days (Simó et al., 2000; Stefels et al., 2007), the lengthier bacterial DMS turnover times in B3 point towards the importance of community-associated DMS production in fuelling DMS in surface waters. Community DMS production may have included indirect processes such as zooplankton grazing, viral lysis, and senescence, as well as direct algal DMSP-lyase activity associated with the presence of certain species of dinoflagellates and coccolithophores (Niki et al., 2000; Wolfe and Steinke, 1996), ubiquitous in subantarctic waters in early March and potential algal oxidative stress associated to light or nutrient availability (Stefels et al., 2007; Sunda et al., 2002).

Another indication of the relative importance of phytoplankton-mediated DMS production in B3 stations can be found in the comparison of standing stocks of DMS relative to $\mathrm{DMSP}_{\mathrm{t}}$ which averaged 0.07 and $0.05 \mathrm{~mol}: \mathrm{mol}$ in $\mathrm{B} 1$ and $\mathrm{B} 2$, respectively, and increased to a mean of $0.15 \mathrm{~mol}: \mathrm{mol}$ in B3. This higher average DMS: $\mathrm{DMSP}_{\mathrm{t}}$ molar ratio suggests stronger $\mathrm{DMSP}_{\mathrm{p}}$-to-DMS conversion efficiency in this particular sampling cluster. Further, albeit limited, information on net community-associated DMS production is provided by net changes in DMS concentrations (Fig. 6) calculated as the difference between concentrations at the beginning and at the end of the $6 \mathrm{~h}$ pre-acclimation incubations under in situ light conditions. These net changes include all sources and sinks of DMS (except for ventilation). Net changes in DMS concentrations over the $6 \mathrm{~h}$ period showed overall accumulation of DMS in the incubation experiments (maximum of $10.8 \mathrm{nmol} \mathrm{L}^{-1}$ at station 9 in B3). An exception to the accumulation trend was seen at station 8 , where a net consumption of DMS $\left(-1.1 \mathrm{nmol} \mathrm{L}^{-1}\right)$ took place over the $6 \mathrm{~h}$ incubation at station 8 . Coarse calculations that assume steady-state conditions suggest that transposing these net changes over a daily period amounts to a mean net community production of DMS from DMSP $\mathrm{D}_{\mathrm{t}}$ of $15.2 \pm 16.4 \mathrm{nmol} \mathrm{L}^{-1}$ day $^{-1}(n=6)$ throughout the stations where data were available. This rough mean estimate is almost 3 times as high as the gross microbial production of DMS from DMSP ${ }_{\mathrm{d}}$ (average of $5.3 \pm 9.9 \mathrm{nmol} \mathrm{L}^{-1}$ day $^{-1}$, $n=6$ ) at the same stations (stations 3, 5, 6, 7, 8, and 9). The microbial DMS production rates from $\mathrm{DMSP}_{d}$ in this study are also considerably lower than several of the community net production rates required to support microlayer DMS (range of -1445 to $5529 \mathrm{nmol} \mathrm{L}^{-1} \mathrm{~h}^{-1}$ ) reported by Walker et al. (2016). Estimates of the relative importance of phytoplankton-mediated DMS production

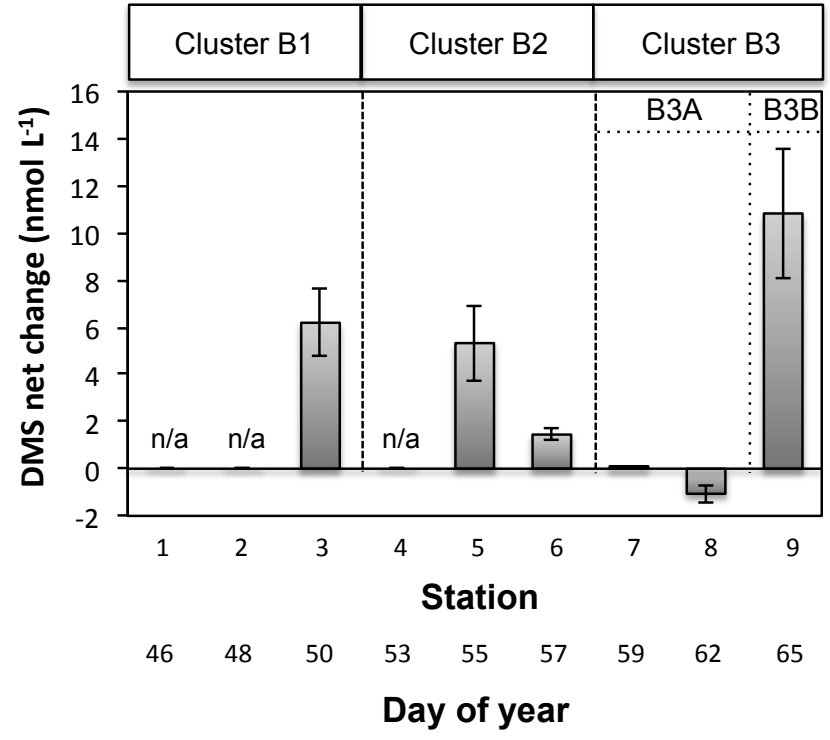

Figure 6. Net changes in DMS concentrations calculated as the difference between $\mathrm{T} 0$ and T6 values during $6 \mathrm{~h}$ incubation experiments conducted in quartz bottles (at in situ light and temperature conditions) on the deck of the ship during the SOAP voyage in February and March 2012. Stacks and error bars indicate mean and standard deviation of triplicate samples. NA indicates data that are not available.

are scarce; however, a study conducted in the waters of the North Atlantic during a summer coccolithophore bloom suggested that as much as $74 \%$ of the potential DMSP-lyase activity occurred in the $>10 \mu \mathrm{m}$ particulate fraction, which contained a high proportion of dinoflagellates (Steinke et al., 2002). Altogether, our findings support the view that indirect and direct processes of phytoplankton-mediated DMS production were important contributors to standing stocks of DMS in the near-surface waters of the STF during austral summer.

\section{Conclusions}

Our study provides information on both concentrations and cycling of dimethylated sulfur compounds within waters of the NEWZ and more specifically in an oceanic frontal region. The three distinct phytoplankton blooms sampled were shown to be hotspots for concentrations of DMS (max of $14.5 \mathrm{nmol} \mathrm{L}^{-1}$ ) and DMSP $\left(\max\right.$ of $160 \mathrm{nmol} \mathrm{L}^{-1}$ ). Regardless of physicochemical and biological differences in bloom dynamics across the subantarctic and subtropical waters investigated, pools of $\mathrm{DMSP}_{\mathrm{t}}$ varied in concert with stocks of Chl $a$, likely because of the dominance of DMSP-rich phytoplankton groups such as dinoflagellates and coccolithophores. The significant relationship between Chl $a$ and DMSP D $\left._{\mathrm{s}}=0.83, p<0.01\right)$ across blooms suggests that autotrophic biomass may be a reasonable predictor 
of DMSP for this region during austral summer. The high availability of reduced sulfur fully satisfied sulfur requirements of the microorganisms, leading to overall low microbial sulfur assimilation efficiencies from $\operatorname{DMSP}_{d}(<5 \%)$. Microbial yields of DMS varied 4-fold over the subtropical front $(4-17 \%)$ and were significantly correlated with bacterial protein synthesis rates, lending support to the idea that supplies of $\mathrm{DMSP}_{\mathrm{d}}$ were non-limiting. Microbially mediated DMS production from $\mathrm{DMSP}_{\mathrm{d}}$ generally ranged between 0.1 and $6.2 \mathrm{nmol} \mathrm{DMS} \mathrm{L}^{-1}$ day $^{-1}$ but was as high as $27 \mathrm{nmolDMS} \mathrm{L}^{-1}$ day $^{-1}$ at station 5. The comparison between standing stocks of DMS and microbially mediated DMS production rates suggests that bacteria alone could not have sustained DMS concentrations in near-surface waters at most stations in this study. These results point towards phytoplankton-associated production of DMS as an important co-driver of DMS pools in the surface waters on either side of the STF. While the STF was already a known region of high biological activity, results from the current study reinforce the hypothesis that the STF also supports high DMSPto-DMS conversions largely related to its abundant biogenic sulfur compounds. These findings could have important implications for global sulfur budgets and climate considering that the STF covers several hundred kilometres in a ring encircling a part of the globe with little anthropogenic influence, and where productive plankton blooms may persist over several months.

Data availability. Data are available by contacting the lead author.

Author contributions. MLi and MLe designed the experiments and MLi, CSL, CFW, KAS, and AM carried out the experiments and performed the measurements in the field. RPK produced and provided ${ }^{35} \mathrm{~S}_{-} \mathrm{DMSP}_{\mathrm{d}}$ for the radiotracer experiments. MLi prepared the paper with contributions from all co-authors.

Competing interests. The authors declare that they have no conflict of interest.

Special issue statement. This article is part of the special issue "Surface Ocean Aerosol Production (SOAP) (ACP/OS interjournal SI)". It does not belong to a conference.

Acknowledgements. We thank Captain Evan Solly and the entire crew of the R/V Tangaroa; Els Maas for facilitating radio-isotope work during the research cruise; F. Hoe Chang for coccolithophore abundance data; Anathea Albert for ${ }^{35}$ S-DMSP scintillation counts; Timothy Burrell and Karen Thompson for bacterial production scintillation counts; Matt Walkington for irradiance data processing and validation, as well as CTD operations; Marieke van Kooten for nitrate measurements; and Murray Smith for MLD calculations.
This paper is a contribution to the research programmes of Québec-Océan and the Biology Department of Laval University as well as to the New Zealand Surface Ocean Lower Atmosphere Study (SOLAS). This study was supported by funding from NIWA's Climate and Atmosphere Research Programme 3 Role of the oceans (2015/16 SCI) and a postdoctoral fellowship (CO1X0911) for Carolyn F. Walker from the New Zealand Ministry for Business, Innovation and Employment (MBIE). Ronald P. Kiene acknowledges support from the National Science Foundation (grants OCE-0928968 and OCE-1436576).

Edited by: Mike Harvey

Reviewed by: Maria Vila-Costa and one anonymous referee

\section{References}

Albrecht, B. A.: Aerosols, Cloud Microphysics, and Fractional Cloudiness, Science, 245, 1227-1230, 1989.

Alcolombri, U., Ben-Dor, S., Feldmesser, E., Levin, Y., Tawfik, D. S., and Vardi, A.: Identification of the algal dimethyl sulfidereleasing enzyme: A missing link in the marine sulfur cycle, Science, 348, 1466-1469, https://doi.org/10.1126/science.aab1586, 2015.

Amin, S. A., Hmelo, L. R., van Tol, H. M., Durham, B. P., Carlson, L. T., Heal, K. R., Morales, R. L., Berthiaume, C. T., Parker, M. S., Djunaedi, B., Ingalls, A. E., Parsek, M. R., Moran, M. A., and Armbrust, E. V.: Interaction and signalling between a cosmopolitan phytoplankton and associated bacteria, Nature, 522, 98-101, https://doi.org/10.1038/nature14488, 2015.

Andreae, M. O. and Crutzen, P. J.: Atmospheric Aerosols: Biogeochemical Sources and Role in Atmospheric Chemistry, Science, 276, 1052-1058, https://doi.org/10.1126/science.276.5315.1052, 1997.

Andreae, M. O., Ferek, R. J., Bermond, F., Byrd, K. P., Engstrom, R. T., Hardin, S., Houmere, P. D., LeMarrec, F., Raemdonck, H., and Chatfield, R. B.: Dimethyl sulfide in the marine atmosphere, J. Geophys. Res., 90, 12891-12900, https://doi.org/10.1029/JD090iD07p12891, 1985.

Ångström, A.: Atmospheric turbidity, global illumination and planetary albedo of the earth, Tellus, 14, 435-450, https://doi.org/10.1111/j.2153-3490.1962.tb01356.x, 1962.

Archer, S. D., Safi, K., Hall, A., Cummings, D. G., and Harvey, M.: Grazing suppression of dimethylsulphoniopropionate (DMSP) accumulation in iron-fertilised, sub-Antarctic waters, Deep-Sea Res. Pt. II, 58, 839-850, https://doi.org/10.1016/j.dsr2.2010.10.022, 2011.

Asher, E., Dacey, J. W., Ianson, D., Peña, A., and Tortell, P. D.: Concentrations and cycling of DMS, DMSP, and DMSO in coastal and offshore waters of the Subarctic Pacific during summer, 2010-2011, J. Geophys. Res.-Oceans, 122, 3269-3286, https://doi.org/10.1002/2016JC012465, 2017.

Balch, W. M., Drapeau, D. T., Bowler, B. C., Lyczskowski, E., Booth, E. S., and Alley, D.: The contribution of coccolithophores to the optical and inorganic carbon budgets during the Southern Ocean Gas Exchange Experiment: New evidence in support of the Great Calcite Belt hypothesis, J. Geophys. Res.-Oceans, 116, C00F06, https://doi.org/10.1029/2011JC006941, 2011. 
Bates, T. S., Lamb, B. K., Guenther, A., Dignon, J., and Stoiber, R. E.: Sulfur emissions to the atmosphere from natural sourees, J. Atmos. Chem., 14, 315-337, https://doi.org/10.1007/BF00115242, 1992.

Belkin, I. M., Cornillon, P. C., and Sherman, K.: Fronts in Large Marine Ecosystems, Prog. Oceanogr., 81, 223-236, https://doi.org/10.1016/j.pocean.2009.04.015, 2009.

Bell, T. G., De Bruyn, W., Marandino, C. A., Miller, S. D., Law, C. S., Smith, M. J., and Saltzman, E. S.: Dimethylsulfide gas transfer coefficients from algal blooms in the Southern Ocean, Atmos. Chem. Phys., 15, 1783-1794, https://doi.org/10.5194/acp15-1783-2015, 2015.

Bell, W. and Mitchell, R.: Chemotactic and growth responses of marine bacteria to algal extracellular products, Biol. Bull., 143, 265-277, https://doi.org/10.2307/1540052, 1972.

Belviso, S., Kim, S.-K., Rassoulzadegan, F., Krajka, B., Nguyen, B. C., Mihalopoulos, N., and Buat-Menard, P.: Production of dimethylsulfonium propionate (DMSP) and dimethylsulfide (DMS) by a microbial food web, Limnol. Oceanogr., 35, 1810-1821, https://doi.org/10.4319/lo.1990.35.8.1810, 1990.

Bradford-Grieve, J. M., Chang, F. H., Gall, M., Pickmere, S., and Richards, F.: Size-fractionated phytoplankton standing stocks and primary production during austral winter and spring 1993 in the Subtropical Convergence region near New Zealand, New Zeal. J. Mar. Freshw. Res., 31, 201-224, https://doi.org/10.1080/00288330.1997.9516759, 1997.

Bürgermeister, S., Zimmermann, R. L., Georgii, H.-W., Bingemer, H. G., Kirst, G. O., Janssen, M., and Ernst, W.: On the biogenic origin of dimethylsulfide: Relation between chlorophyll, ATP, organismic DMSP, phytoplankton species, and DMS distribution in Atlantic surface water and atmosphere, J. Geophys. Res., 95, 20607, https://doi.org/10.1029/JD095iD12p20607, 1990.

Chang, F. H. and Northcote, L.: Species composition of extant coccolithophores including twenty six new records from the southwest Pacific near New Zealand, Mar. Biodivers. Rec., 9, 1-13, https://doi.org/10.1186/s41200-016-0077-7, 2016.

Charlson, R. J., Lovelock, J. E., Andreae, M. O., and Warren, S. G.: Oceanic phytoplankton, atmospheric sulphur, cloud albedo and climate, Nature, 326, 655-661, 1987.

Cooper, M. B. and Smith, A. G.: Exploring mutualistic interactions between microalgae and bacteria in the omics age, Curr. Opin. Plant Biol., 26, 147-153, https://doi.org/10.1016/j.pbi.2015.07.003, 2015.

Cuhel, R. and Taylor, C.: Assimilatory Sulfur Metabolism in Marine Microorganisms: Characteristics and Regulation of Sulfate Transport in Pseudomonas halodurans and Alteromonas luteoviolaceust, J. Bacteriol., 147, 340-349, 1981.

Dacey, J. W. H. and Wakeham, S. G.: Oceanic Dimethylsulfide: Production During Zooplankton Grazing on Phytoplankton, Science, 233, 1314, https://doi.org/10.1126/science.233.4770.1314, 1986.

Dacey, J. W. H., Howse, F. A., Michaels, A. F., and Wakeham, S. G.: Temporal variability of dimethylsulfide and dimethylsulfoniopropionate in the Sargasso Sea, Deep-Sea Res. Pt. I, 45, 20852104, https://doi.org/10.1016/S0967-0637(98)00048-X, 1998.

Daniels, C. J., Sheward, R. M., and Poulton, A. J.: Biogeochemical implications of comparative growth rates of Emiliania huxleyi and Coccolithus species, Biogeosciences, 11, 6915-6925, https://doi.org/10.5194/bg-11-6915-2014, 2014.
Doron, M., Babin, M., Mangin, A., and Hembise, O.: Estimation of light penetration, and horizontal and vertical visibility in oceanic and coastal waters from surface reflectance, J. Geophys. Res.Oceans, 112, C06003, https://doi.org/10.1029/2006JC004007, 2007.

Fagerbakke, K. M., Heldal, M., and Norland, S.: Content of carbon, nitrogen, oxygen, sulfur and phosphorus in native aquatic and cultured bacteria, Aquat. Microb. Ecol., 10, 15-27, https://doi.org/10.3354/ame010015, 1996.

Franklin, D. J., Steinke, M., Young, J., Probert, I., and Malin, G.: Dimethylsulphoniopropionate (DMSP), DMSPlyase activity (DLA) and dimethylsulphide (DMS) in 10 species of coccolithophore, Mar. Ecol. Prog. Ser., 410, 13-23, https://doi.org/10.3354/meps08596, 2010.

Galí, M., Saló, V., Almeda, R., Calbet, A., and Simó, R.: Stimulation of gross dimethylsulfide (DMS) production by solar radiation, Geophys. Res. Lett., 38, L15612, https://doi.org/10.1029/2011GL048051, 2011.

Gondwe, M., Krol, M., Gieskes, W., Klaassen, W., and de Baar, H.: The contribution of ocean-leaving DMS to the global atmospheric burdens of DMS, MSA, $\mathrm{SO}_{2}$, and NSS $\mathrm{SO}_{4}=$, Global Biogeochem. Cy., 17, 1056, https://doi.org/10.1029/2002GB001937, 2003.

Herndl, G. J., Muller-Niklas, G., and Frick, J.: Major role of ultraviolet-B in controlling bacterioplankton growth in the surface layer of the ocean, Nature, 361, 717-719, https://doi.org/10.1038/361717a0, 1993.

Holligan, P. M., Turner, S. M., and Liss, P. S.: Measurements of dimethyl sulphide in frontal regions, Cont. Shelf Res., 7, 213224, https://doi.org/10.1016/0278-4343(87)90080-X, 1987.

Holligan, P. M., Fernández, E., Aiken, J., Balch, W. M., Boyd, P., Burkill, P. H., Finch, M., Groom, S. B., Malin, G., Muller, K., Purdie, D. A., Robinson, C., Trees, C. C., Turner, S. M., and Wal, P.: A biogeochemical study of the coccolithophore, Emiliania huxleyi, in the North Atlantic, Glob. Biogeochem. Cy., 7, 879-900, https://doi.org/10.1029/93GB01731, 1993.

Jones, G. B., Curran, M. A. J., Swan, H. B., Greene, R. M., Griffiths, F. B., and Clementson, L. A.: Influence of different water masses and biological activity on dimethylsulphide and dimethylsulphoniopropionate in the subantarctic zone of the Southern Ocean during ACE 1, J. Geophys. Res.-Atmos., 103, 16691-16701, https://doi.org/10.1029/98JD01200, 1998.

Kara, A. B., Rochford, P. A., and Hurlburt, H. E.: An optimal definition for ocean mixed layer depth, J. Geophys. Res.-Oceans, 105, 16803-16821, https://doi.org/10.1029/2000JC900072, 2000.

Keller, M. D.: Dimethyl Sulfide Production and Marine Phytoplankton: The Importance of Species Composition and Cell Size, Biol. Oceanogr., 6, 375-382, https://doi.org/10.1080/01965581.1988.10749540, 1989.

Kettle, A. J., Andreae, M. O., Amouroux, D., Andreae, T. W., Bates, T. S., Berresheim, H., Bingemer, H., Boniforti, R., Curran, M. A. J., DiTullio, G. R., Helas, G., Jones, G. B., Keller, M. D., Kiene, R. P., Leck, C., Levasseur, M., Malin, G., Maspero, M., Matrai, P., McTaggart, A. R., Mihalopoulos, N., Nguyen, B. C., Novo, A., Putaud, J. P., Rapsomanikis, S., Roberts, G., Schebeske, G., Sharma, S., Simó, R., Staubes, R., Turner, S., and Uher, G.: A global database of sea surface dimethylsulfide (DMS) measurements and a procedure to predict sea surface DMS as a function 
of latitude, longitude, and month, Global Biogeochem. Cy., 13, 399-444, https://doi.org/10.1029/1999GB900004, 1999.

Kiene, R. P. and Linn, L. J.: Distribution and turnover of dissolved DMSP and its relationship with bacterial production and dimethylsulfide in the Gulf of Mexico, Limnol. Oceanogr., 45, 849-861, https://doi.org/10.4319/lo.2000.45.4.0849, 2000a.

Kiene, R. P. and Linn, L. J.: The fate of dissolved dimethylsulfoniopropionate (DMSP) in seawater: Tracer studies using 35S-DMSP, Geochim. Cosmochim. Ac., 64, 2797-2810, https://doi.org/10.1016/S0016-7037(00)00399-9, 2000b.

Kiene, R. P. and Slezak, D.: Low dissolved DMSP concentrations in seawater revealed by small-volume gravity filtration and dialysis sampling, Limnol. Oceanogr. Meth., 4, 80-95, https://doi.org/10.4319/lom.2006.4.80, 2006.

Kiene, R. P., Linn, L. J., Gonzalez, J., Moran, M. A., and Bruton, J. A.: Dimethylsulfoniopropionate and methanethiol are important precursors of methionine and protein-sulfur in marine bacterioplankton, Appl. Environ. Microbiol., 65, 4549-4558, 1999.

Kiene, R. P., Linn, L. J., and Bruton, J. A.: New and important roles for DMSP in marine microbial communities, J. Sea Res., 43, 209-224, https://doi.org/10.1016/S1385-1101(00)00023-X, 2000.

Kiene, R. P., Kieber, D. J., Slezak, D., Toole, D. A., Del Valle, D. A., Bisgrove, J., Brinkley, J., and Rellinger, A.: Distribution and cycling of dimethylsulfide, dimethylsulfoniopropionate, and dimethylsulfoxide during spring and early summer in the Southern Ocean south of New Zealand, Aquat. Sci., 69, 305-319, https://doi.org/10.1007/s00027-007-0892-3, 2007.

Kirchman, D., K'nees, E., and Hodson, R.: Leucine incorporation and its potential as a measure of protein synthesis by bacteria in natural aquatic systems, Appl. Environ. Microbiol., 49, 599-607, https://doi.org/10.1128/AEM.67.4.1775-1782.2001, 1985.

Kloster, S., Feichter, J., Maier-Reimer, E., Six, K. D., Stier, P., and Wetzel, P.: DMS cycle in the marine ocean-atmosphere system - a global model study, Biogeosciences, 3, 29-51, https://doi.org/10.5194/bg-3-29-2006, 2006.

Kwint, R. L. J. and Kramer, K. J. M.: Annual cycle of the production and fate of DMS and DMSP in a marine coastal system, Mar. Ecol. Prog. Ser., 134, 217-224, https://doi.org/10.3354/meps134217, 1996.

Lana, A., Bell, T. G., Simó, R., Vallina, S. M., Ballabrera-Poy, J., Kettle, A. J., Dachs, J., Bopp, L., Saltzman, E. S., Stefels, J., Johnson, J. E., and Liss, P. S.: An updated climatology of surface dimethlysulfide concentrations and emission fluxes in the global ocean, Global Biogeochem. Cy., 25, GB1004, https://doi.org/10.1029/2010GB003850, 2011.

Lana, A., Simó, R., Vallina, S. M., and Dachs, J.: Re-examination of global emerging patterns of ocean DMS concentration, Biogeochemistry, 110, 173-182, https://doi.org/10.1007/s10533-0119677-9, 2012

Laroche, D., Vézina, A. F., Levasseur, M., Gosselin, M., Stefels, J., Keller, M. D., Matrai, P. A., and Kwint, R. L. J.: DMSP synthesis and exudation in phytoplankton: A modeling approach, Mar. Ecol. Prog. Ser., 180, 37-49, https://doi.org/10.3354/meps180037, 1999.

Law, C. S., Woodward, E. M. S., Ellwood, M. J., Marriner, A., Bury, S. J., and Safi, K. A.: Response of surface nutrient inventories and nitrogen fixation to a tropical cyclone in the southwest Pacific, Limnol. Oceanogr., 56, 1372-1385, https://doi.org/10.4319/lo.2011.56.4.1372, 2011.

Law, C. S., Smith, M. J., Harvey, M. J., Bell, T. G., Cravigan, L. T., Elliott, F. C., Lawson, S. J., Lizotte, M., Marriner, A., McGregor, J., Ristovski, Z., Safi, K. A., Saltzman, E. S., Vaattovaarra, P., and Walker, C. F.: Overview and preliminary results of the Surface Ocean Aerosol Production (SOAP) campaign, Atmos. Chem. Phys., 17, 13645-13667, https://doi.org/10.5194/acp-1713645-2017, 2017.

Lebaron, P., Parthuisot, N., and Catala, P.: Comparison of blue nuclei acid dyes for flow cytometric enumeration of bacteria in aquatic systems, Appl. Environ. Microbiol., 64, 1725-1730, 1998.

Leck, C., Larsson, U., Bågander, L. E., Johansson, S., and Hajdu, S.: Dimethyl sulfide in the Baltic Sea: Annual variability in relation to biological activity, J. Geophys. Res., 95, 3353, https://doi.org/10.1029/JC095iC03p03353, 1990.

Legendre, P. and Legendre, L.: Numerical Ecology, 2nd English Edn., Elsevier Science B. V., Amsterdam, 853 pp., 1998.

Levasseur, M., Michaud, S., Egge, J., Cantin, G., Nejstgaard, J. C., Sanders, R., Fernandez, E., Solberg, P. T., Heimdal, B., and Gosselin, M.: Production of DMSP and DMS during a mesocosm study of an Emiliania huxleyi bloom: influence of bacteria and Calanus finmarchicus grazing, Mar. Biol., 126, 609-618, https://doi.org/10.1007/BF00351328, 1996.

Liss, P. S., Hatton, A. D., Malin, G., Nightingale, P. D., and Turner, S. M.: Marine sulphur emissions, Philos. T. Roy. Soc. Lond. B, 352, 159-169, 1997.

Liu, C. Y., Kieber, D. J., Yang, G. P., Xue, C., Wang, L. L., and Liu, H. H.: Evidence for the mutual effects of dimethylsulfoniopropionate and nitric oxide during the growth of marine microalgae, Nitric Oxide - Biol. Chem., 42, 54-61, https://doi.org/10.1016/j.niox.2014.09.003, 2014.

Lizotte, M., Levasseur, M., Kudo, I., Suzuki, K., Tsuda, A., Kiene, R. P., and Scarratt, M. G.: Iron-induced alterations of bacterial DMSP metabolism in the western subarctic Pacific during SEEDS-II, Deep.-Res. Pt. II, 56, 2889-2898, https://doi.org/10.1016/j.dsr2.2009.06.012, 2009.

Lizotte, M., Levasseur, M., Michaud, S., Scarratt, M. G., Merzouk, A., Gosselin, M., Pommier, J., Rivkin, R. B., and Kiene, R. P.: Macroscale patterns of the biological cycling of dimethylsulfoniopropionate (DMSP) and dimethylsulfide (DMS) in the Northwest Atlantic, Biogeochemistry, 110, 183-200, https://doi.org/10.1007/s10533-011-9698-4, 2012.

Llido, J., Garçon, V., Lutjeharms, J. R. E., and Sudre, J.: Event-scale blooms drive enhanced primary productivity at the Subtropical Convergence, Geophys. Res. Lett., 32, L15611, https://doi.org/10.1029/2005GL022880, 2005.

Longhurst, A. R.: Ecological geography of the sea, Academic Press, Burlington, MA, 542 pp., 2007.

Lovelock, J. E., Maggs, R. J., and Rasmussen, R. A.: Atmospheric dimethyl sulfide and the natural sulfur cycle, Nature, 237, 452453, https://doi.org/10.1038/237452a0, 1972.

Luce, M., Levasseur, M., Scarratt, M. G., Michaud, S., Royer, S. J., Kiene, R., Lovejoy, C., Gosselin, M., Poulin, M., Gratton, Y., and Lizotte, M.: Distribution and microbial metabolism of dimethylsulfoniopropionate and dimethylsulfide during the 2007 Arctic ice minimum, J. Geophys. Res.-Oceans, 116, C00G06, https://doi.org/10.1029/2010JC006914, 2011. 
Malin, G.: Biological oceanography: Sulphur, climate and the microbial maze, Nature, 387, 857-859, 1997.

Malin, G., Turner, S., Liss, P., Holligan, P., and Harbour, D.: Dimethylsulphide and dimethylsulphoniopropionate in the Northeast atlantic during the summer coccolithophore bloom, Deep-Sea Res. Pt. I, 40, 1487-1508, https://doi.org/10.1016/0967-0637(93)90125-M, 1993.

Malmstrom, R. R., Kiene, R. P., Cottrell, M. T., and Kirchman, D. L.: Contribution of SAR11 Bacteria to Dissolved Dimethylsulfoniopropionate and Amino Acid Uptake in the North Atlantic Ocean, Appl. Environ. Microbiol., 70, 4129-4135, https://doi.org/10.1128/AEM.70.7.4129-4135.2004, 2004a.

Malmstrom, R. R., Kiene, R. P., and Kirchman, D. L.: Identification and enumeration of bacteria assimilating dimethylsulfoniopropionate (DMSP) in the North Atlantic and Gulf of Mexico, Limnol. Oceanogr., 49, 597-606, 2004b.

Malmstrom, R. R., Kiene, R. P., Vila, M., and Kirchman, D. L.: Dimethylsulfoniopropionate (DMSP) assimilation by Synechococcus in the Gulf of Mexico and northwest Atlantic Ocean, Limnol. Oceaneonogr., 50, 1924-1931, 2005.

Marandino, C. A., Tegtmeier, S., Krüger, K., Zindler, C., Atlas, E. L., Moore, F., and Bange, H. W.: Dimethylsulphide (DMS) emissions from the western Pacific Ocean: A potential marine source for stratospheric sulphur?, Atmos. Chem. Phys., 13, 8427-8437, https://doi.org/10.5194/acp-13-8427-2013, 2013.

Matrai, P. A. and Keller, M. D.: Dimethylsulfide in a large-scale coccolithophore bloom in the Gulf of Maine, Cont. Shelf Res., 13, 831-843, https://doi.org/10.1016/0278-4343(93)90012-M, 1993.

Matrai, P. A. and Keller, M. D.: Total organic sulfur and dimethylsulfoniopropionate in marine phytoplankton: intracellular variations, Mar. Biol., 119, 61-68, https://doi.org/10.1007/BF00350107, 1994.

Matrai, P. A., Cooper, D. J., and Saltzman, E. S.: Frontal enhancement of dimethylsulfide concentrations across a Gulf Stream meander, J. Mar. Syst., 7, 1-8, https://doi.org/10.1016/09247963(95)00013-5, 1996.

Merzouk, A., Levasseur, M., Scarratt, M. G., Michaud, S., Rivkin, R. B., Hale, M. S., Kiene, R. P., Price, N. M., and Li, W. K. W.: DMSP and DMS dynamics during a mesoscale iron fertilization experiment in the Northeast Pacific - Part II: Biological cycling, Deep-Sea Res. Pt. II, 53, 2370-2383, https://doi.org/10.1016/j.dsr2.2006.05.022, 2006.

Merzouk, A., Levasseur, M., Scarratt, M., Michaud, S., Lizotte, M., Rivkin, R. B., and Kiene, R. P.: Bacterial DMSP metabolism during the senescence of the spring diatom bloom in the Northwest Atlantic, Mar. Ecol. Prog. Ser., 369, 1-11, https://doi.org/10.3354/meps07664, 2008.

Metzl, N., Tilbrook, B., and Poisson, A.: Sea surface fugacity of carbon dioxide measurements in the Indian and Southern Oceans obtained during MINERVE-29/ANTARES-II cruise, PANGAEA, https://doi.org/10.1034/j.1600-0889.1999.t01-300008.x, 1999.

Miles, C. J., Bell, T. G., and Lenton, T. M.: Testing the relationship between the solar radiation dose and surface DMS concentrations using in situ data, Biogeosciences, 6, 1927-1934, https://doi.org/10.5194/bg-6-1927-2009, 2009.

Miles, C. J., Bell, T. G., and Suntharalingam, P.: Investigating the inter-relationships between water attenuated irradiance, pri- mary production and DMS(P), Biogeochemistry, 110, 201-213, https://doi.org/10.1007/s10533-011-9697-5, 2012.

Motard-Côté, J., Levasseur, M., Scarratt, M. G., Michaud, S., Gratton, Y., Rivkin, R. B., Keats, K., Gosselin, M., Tremblay, J.-É., Kiene, R. P., and Lovejoy, C.: Distribution and metabolism of dimethylsulfoniopropionate (DMSP) and phylogenetic affiliation of DMSP-assimilating bacteria in northern Baffin Bay/Lancaster Sound, J. Geophys. Res.-Oceans, 117, C00G11, https://doi.org/10.1029/2011JC007330, 2012.

Nemcek, N., Ianson, D., and Tortell, P. D.: A high-resolution survey of DMS, $\mathrm{CO}_{2}$, and $\mathrm{O}_{2} / \mathrm{Ar}$ distributions in productive coastal waters, Global Biogeochem. Cy., 22, GB2009, https://doi.org/10.1029/2006GB002879, 2008.

Niki, T., Kunugi, M., and Otsuki, A.: DMSP-lyase activity in five marine phytoplankton species: its potential importance in DMS production, Mar. Biol., 136, 759-764, https://doi.org/10.1007/s002279900235, 2000.

Paasche, E.: A review of the coccolithophorid Emiliania huxleyi (Prymnesiophyceae), with particular reference to growth, coccolith formation, and calcification-photosynthesis interactions, Phycologia, 40, 503-529, https://doi.org/10.2216/i0031-8884-40-6503.1, 2001.

Pinhassi, J., Simó, R., González, J. M., Vila, M., Alonso-Sáez, L., Kiene, R. P., Moran, M. A., and Pedrós-Alió, C.: Dimethylsulfoniopropionate turnover is linked to the composition and dynamics of the bacterioplankton assemblage during a microcosm phytoplankton bloom, Appl. Environ. Microbiol., 71, 7650-7660, https://doi.org/10.1128/AEM.71.12.7650-7660.2005, 2005.

Quinn, P. K. and Bates, T. S.: The case against climate regulation via oceanic phytoplankton sulphur emissions, Nature, 480, 5156, https://doi.org/10.1038/nature10580, 2011.

Quinn, P. K., Coffman, D. J., Johnson, J. E., Upchurch, L. M., and Bates, T. S.: Small fraction of marine cloud condensation nuclei made up of sea spray aerosol, Nat. Geosci., 10, 674-679, https://doi.org/10.1038/ngeo3003, 2017.

Ramanan, R., Kim, B. H., Cho, D. H., Oh, H. M., and Kim, H. S.: Algae-bacteria interactions: Evolution, ecology and emerging applications, Biotechnol. Adv., 34, 14-29, https://doi.org/10.1016/j.biotechadv.2015.12.003, 2016.

Reisch, C. R., Moran, M. A., and Whitman, W. B.: Bacterial catabolism of dimethylsulfoniopropionate (DMSP), Front. Microbiol., 2, 172, https://doi.org/10.3389/fmicb.2011.00172, 2011.

Rhodes, L. L., Peake, B., MacKenzie, A. L., and Marwick, S.: Coccolithophores Gephyrocapsa oceanica and Emiliania huxleyi (Prymnesiophyceae $=$ Haptophyceae) in New Zealand's coastal waters: Characteristics of blooms and growth in laboratory culture, New Zealand J. Mar. Freshw. Res., 29, 345-357, https://doi.org/10.1080/00288330.1995.9516669, 1994.

Rieck, A., Herlemann, D. P. R., Jürgens, K., and Grossart, H. P.: Particle-associated differ from free-living bacteria in surface waters of the baltic sea, Front. Microbiol., 6, 1297, https://doi.org/10.3389/fmicb.2015.01297, 2015.

Rowden, A. A., Clark, M. R., and Wright, I. C.: Physical characterisation and a biologically focused classification of "seamounts" in the New Zealand region, New Zeal. J. Mar. Freshw. Res., 39, 1039-1059, https://doi.org/10.1080/00288330.2005.9517374, 2005. 
Royer, S.-J., Levasseur, M., Lizotte, M., Arychuk, M., Scarratt, M. G., Wong, C. S., Lovejoy, C., Robert, M., Johnson, K., Peña, A., Michaud, S., and Kiened, R. P.: Microbial dimethylsulfoniopropionate (DMSP) dynamics along a natural iron gradient in the northeast subarctic Pacific, Limnol. Oceanogr., 55, 1614-1626, https://doi.org/10.4319/lo.2010.55.4.1614, 2010.

Ruiz-González, C., Simó, R., Vila-Costa, M., Sommaruga, R., and Gasol, J. M.: Sunlight modulates the relative importance of heterotrophic bacteria and picophytoplankton in DMSP-sulphur uptake, ISME J., 6, 650-659, https://doi.org/10.1038/ismej.2011.118, 2011.

Ruiz-González, C., Galí, M., Gasol, J. M., and Simó, R.: Sunlight effects on the DMSP-sulfur and leucine assimilation activities of polar heterotrophic bacterioplankton, Biogeochemistry, 110, 5774, https://doi.org/10.1007/s10533-012-9699-y, 2012.

Ruiz-González, C., Simó, R., Sommaruga, R., and Gasol, J. M.: Away from darkness: a review on the effects of solar radiation on heterotrophic bacterioplankton activity, Front. Microbiol., 4, 1-24, https://doi.org/10.3389/fmicb.2013.00131, 2013.

Sadeghi, A., Dinter, T., Vountas, M., Taylor, B., Altenburg-Soppa, M., and Bracher, A.: Remote sensing of coccolithophore blooms in selected oceanic regions using the PhytoDOAS method applied to hyper-spectral satellite data, Biogeosciences, 9, 21272143, https://doi.org/10.5194/bg-9-2127-2012, 2012.

Safi, K. A., Hewitt, J. E., and Talman, S. G.: The effect of high inorganic seston loads on prey selection by the suspension-feeding bivalve, Atrina zelandica, J. Exp. Mar. Biol. Ecol., 344, 136-148, https://doi.org/10.1016/j.jembe.2006.12.023, 2007.

Sarmiento, J. L., Gruber, N., Brzezinski, M. A., and Dunne, J. P.: High-latitude controls of thermocline nutrients and low latitude biological productivity, Nature, 427, 56-60, https://doi.org/10.1038/nature02127, 2004.

Scarratt, M., Cantin, G., Levasseur, M., and Michaud, S.: Particle size-fractionated kinetics of DMS production: Where does DMSP cleavage occur at the microscale?, J. Sea Res., 43, 245252, https://doi.org/10.1016/S1385-1101(00)00019-8, 2000.

Scarratt, M. G., Levasseur, M., Michaud, S., Cantin, G., Gosselin, M., and de Mora, S. J.: Influence of phytoplankton taxonomic profile on the distribution of dimethylsulfide and dimethylsulfoniopropionate in the northwest Atlantic, Mar. Ecol. Prog. Ser., 244, 49-61, 2002.

Schafer, H., Myronova, N., and Boden, R.: Microbial degradation of dimethylsulphide and related $\mathrm{C} 1$-sulphur compounds: organisms and pathways controlling fluxes of sulphur in the biosphere, J. Exp. Bot., 61, 315-334, https://doi.org/10.1093/jxb/erp355, 2010.

Simó, R., Pedros-Alio, C., Malin, G., and Grimalt, J. O.: Biological turnover of DMS, DMSP and DMSO in contrasting open-sea waters, Mar. Ecol. Prog. Ser., 203, 1-11, https://doi.org/10.3354/meps203001, 2000.

Simó, R.: Production of atmospheric sulfur by oceanic plankton: Biogeochemical, ecological and evolutionary links, Trends Ecol. Evol., 16, 287-294, https://doi.org/10.1016/S01695347(01)02152-8, 2001

Simó, R. and Dachs, J.: Global ocean emission of dimethylsulfide predicted from biogeophysical data, Global Biogeochem. Cy., 16, 26-1-26-10, https://doi.org/10.1029/2001GB001829, 2002.
Simó, R. and Pedrós-Alió, C.: Role of vertical mixing in controlling the oceanic production of dimethyl sulphide, Nature, 402, 396399, 1999.

Simó, R., Vila-Costa, M., Alonso-Sáez, L., Cardelús, C., Guadayol, Ó., Vázquez-Dominguez, E., and Gasol, J. M.: Annual DMSP contribution to $\mathrm{S}$ and $\mathrm{C}$ fluxes through phytoplankton and bacterioplankton in a NW Mediterranean coastal site, Aquat. Microb. Ecol., 57, 43-55, https://doi.org/10.3354/ame01325, 2009.

Simon, M. and Azam, F.: Protein content and protein synthesis rates of planktonic marine bacteria, Mar. Ecol. Prog. Ser., 51, 201213, 1989.

Simon, M., Grossart, H. P., Schweitzer, B., and Ploug, H.: Microbial ecology of organic aggregates in aquatic ecosystems, Aquat Microb. Ecol., 28, 175-211, https://doi.org/10.3354/ame028175, 2002.

Slezak, D., Brugger, A., and Herndl, G. J.: Impact of solar radiation on the biological removal of dimethylsulfoniopropionate and dimethylsulfide in marine surface waters, Aquat. Microb. Ecol., 25, 87-97, https://doi.org/10.3354/ame025087, 2001.

Slezak, D., Kiene, R. P., Toole, D. A., Simó, R., and Kieber, D. J.: Effects of solar radiation on the fate of dissolved DMSP and conversion to DMS in seawater, Aquat. Sci., 69, 377-393, https://doi.org/10.1007/s00027-007-0896-z, 2007.

Sokal, R. R. and Rohlf, F. J.: Biometry: the principles and practice of statistics in biological research, 3rd Edn., W. H. Freeman and Co., New York, 887 pp., 1995.

Stefels, J., Dijkhuizen, L., and Gieskes, W. W.: DMSP-lyase activity in a spring phytoplankton bloom off the Dutch coast, related to Phaeocystis sp. abundance, Mar. Ecol. Prog. Ser., 123, 235-243, https://doi.org/10.3354/meps123235, 1995.

Stefels, J., Steinke, M., Turner, S., Malin, G., and Belviso, S.: Environmental constraints on the production and removal of the climatically active gas dimethylsulphide (DMS) and implications for ecosystem modelling, Biogeochemistry, 83, 245-275, https://doi.org/10.1007/s10533-007-9091-5, 2007.

Steinke, M., Malin, G., Turner, S. M., and Liss, P. S.: Determinations of dimethylsulphoniopropionate (DMSP) lyase activity using headspace analysis of dimethylsulphide (DMS), J. Sea Res., 43, 233-244, https://doi.org/10.1016/S1385-1101(00)00024-1, 2000.

Steinke, M., Malin, G., Archer, S. D., Burkill, P. H., and Liss, P. S.: DMS production in a coccolithophorid bloom: Evidence for the importance of dinoflagellate DMSP lyases, Aquat. Microb. Ecol., 26, 259-270, https://doi.org/10.3354/ame026259, 2002.

Strickland, J. D. H. and Parsons, T. R.: A practical handbook of seawater analysis, Fisheries Res., Board of Canada, Ottawa, p. 310, 1972.

Sunda, W., Kieber, D. J., Kiene, R. P., and Huntsman, S.: An antioxidant function for DMSP and DMS in marine algae, Nature, 418, 317-320, https://doi.org/10.1038/nature00851, 2002.

Sutton, P.: Detailed structure of the Subtropical Front over Chatham Rise, east of New Zealand, J. Geophys. Res.-Oceans, 106, 31045-31056, https://doi.org/10.1029/2000JC000562, 2001.

Taylor, B. F. and Gilchrist, D. C.: New Routes for Aerobic Biodegradation of Dimethylsulfoniopropionate, Appl. Environ. Microbiol., 57, 3581-3584, 1991.

Taylor, B. F. and Visscher, P. T.: Metabolic Pathways Involved in DMSP Degradation, in: Biological and Environmental Chemistry of DMSP and Related Sulfonium Compounds, edited by: 
Kiene, R. P., Visscher, P. T., Keller, M. D., and Kirst, G. O., Springer US, Boston, MA, 265-276, 1996.

Todd, J. D., Rogers, R., Li, Y. G., Wexler, M., Bond, P. L., Sun, L., Curson, A. R. J., Malin, G., Steinke, M., and Johnston, A. W. B.: Structural and Regulatory Genes Required to Make the Gas Dimethyl Sulfide in Bacteria, Science, 315, 666-669, 2007.

Toole, D. A., Slezak, D., Kiene, R. P., Kieber, D. J., and Siegel, D. A.: Effects of solar radiation on dimethylsulfide cycling in the western Atlantic Ocean, Deep-Sea Res. Pt. I, 53, 136-153, https://doi.org/10.1016/j.dsr.2005.09.003, 2006.

Tortell, P. D.: Small-scale heterogeneity of dissolved gas concentrations in marine continental shelf waters, Geochem. Geophy. Geosy., 6, Q11M04, https://doi.org/10.1029/2005GC000953, 2005.

Tortell, P. D. and Long, M. C.: Spatial and temporal variability of biogenic gases during the Southern Ocean spring bloom, Geophys. Res. Lett., 36, L01603, https://doi.org/10.1029/2008GL035819, 2009.

Townsend, D. W. and Keller, M. D.: Dimethylsulfide (DMS) and dimethylsulfoniopropionate (DMSP) in relation to phytoplankton in the Gulf of Maine, Mar. Ecol. Prog. Ser., 137, 229-241, https://doi.org/10.3354/meps137229, 1996.

Tracey, D. M., Bull, B., Clark, M. R., and Mackay, K. A.: Fish species composition on seamounts and adjacent slope in New Zealand waters, New Zeal. J. Mar. Freshw. Res., 38, 163-182, https://doi.org/10.1080/00288330.2004.9517226, 2004.

Turner, S. M., Malin, G., Liss, P. S., Harbour, D. S., and Holligan, P. M.: The seasonal variation of dimethyl sulfide and dimethylsulfoniopropionate concentrations in nearshore waters1, Limnol. Oceanogr., 33, 364-375, https://doi.org/10.4319/1o.1988.33.3.0364, 1988.

Twomey, S.: The Influence of Pollution on the Shortwave Albedo of Clouds, J. Atmos. Sci., 34, 1149-1152, https://doi.org/10.1175/15200469(1977)034<1149:TIOPOT>2.0.CO;2, 1977.

Vallina, S. M. and Simó, R.: Strong Relationship Between DMS and the Solar Radiation Dose over the Global Surface Ocean, Science, 315, 506-508, 2007.

Vallina, S. M., Simó, R., and Gassó, S.: What controls CCN seasonality in the Southern Ocean? A statistical analysis based on satellite-derived chlorophyll and CCN and model-estimated $\mathrm{OH}$ radical and rainfall, Global Biogeochem. Cy., 20, GB1014, https://doi.org/10.1029/2005GB002597, 2006.

Van Duyl, F. C., Gieskes, W. W. C., Kop, A. J., and Lewis, W. E.: Biological control of short-term variations in the concentration of DMSP and DMS during a Phaeocystis spring bloom, J. Sea Res., 40, 221-231, https://doi.org/10.1016/S13851101(98)00024-0, 1998.

Vila, M., Simó, R., Kiene, R. P., Pinhassi, J., González, J. M., Moran, M. A., and Pedrós-Alió, C.: Use of Microautoradiography Combined with Fluorescence In Situ Hybridization To Determine Dimethylsulfoniopropionate Incorporation by Marine Bacterioplankton Taxa, Appl. Environ. Microbiol., 70, 46484657, https://doi.org/10.1128/AEM.70.8.4648-4657.2004, 2004.

Vila-Costa, M., Simó, R., Harada, H., Gasol, J. M., Slezak, D., and Kiene, R. P.: Dimethylsulfoniopropionate Uptake by Marine Phytoplankton, Science, 314, 652-654, 2006a.

Vila-Costa, M., Del Valle, D. A., González, J. M., Slezak, D., Kiene, R. P., Sánchez, O., and Simó, R.: Phylogenetic identification and metabolism of marine dimethylsulfide- consuming bacteria, Environ. Microbiol., 8, 2189-2200, https://doi.org/10.1111/j.14622920.2006.01102.x, 2006b.

Vila-Costa, M., Pinhassi, J., Alonso, C., Pernthaler, J., and Simó, R.: An annual cycle of dimethylsulfoniopropionatesulfur and leucine assimilating bacterioplankton in the coastal NW Mediterranean, Environ. Microbiol., 9, 2451-2463, https://doi.org/10.1111/j.1462-2920.2007.01363.x, 2007.

Vila-Costa, M., Kiene, R. P. and Simó, R.: Seasonal variability of the dynamics of dimethylated sulfur compounds in a coastal northwest Mediterranean site, Limnol. Oceanogr., 53, 198-211, https://doi.org/10.4319/lo.2008.53.1.0198, 2008.

Vila-Costa, M., Rinta-Kanto, J. M., Sun, S., Sharma, S., Poretsky, R., and Moran, M. A.: Transcriptomic analysis of a marine bacterial community enriched with dimethylsulfoniopropionate, ISME J., 4, 1410-1420, https://doi.org/10.1038/ismej.2010.62, 2010.

Vila-Costa, M., Rinta-Kanto, J. M., Poretsky, R. S., Sun, S., Kiene, R. P., and Moran, M. A.: Microbial controls on DMSP degradation and DMS formation in the Sargasso Sea, Biogeochemistry, 120, 295-305, https://doi.org/10.1007/s10533-014-9996-8, 2014.

Visscher, P. T., Quist, P., and Gemerden, H.: Methylated Sulfur Compounds in Microbial Mats: In Situ Concentrations and Metabolism by a Colorless Sulfur Bacterium, Appl. Environ. Microbiol., 57, 1758-1763, 1991.

Walker, C. F., Harvey, M. J., Bury, S. J., and Chang, F. H.: Biological and physical controls on dissolved dimethylsulfide over the north-eastern continental shelf of New Zealand, J. Sea Res., 43, 253-264, https://doi.org/10.1016/S1385-1101(00)00017-4, 2000.

Walker, C. F., Harvey, M. J., Smith, M. J., Bell, T. G., Saltzman, E. S., Marriner, A. S., Mcgregor, J. A., and Law, C. S.: Assessing the potential for dimethylsulfide enrichment at the sea surface and its influence on air-sea flux, Ocean Sci., 12, 1033-1048, https://doi.org/10.5194/os-12-1033-2016, 2016.

Weeks, S. J. and Shillington, F. A.: Phytoplankton pigment distribution and frontal structure in the subtropical convergence region south of Africa, Deep-Sea Res. Pt. I Oceanogr. Res. Pap., 43, 739-768, https://doi.org/10.1016/0967-0637(96)00016-7, 1996.

Wolfe, G. V and Steinke, M.: Grazing-activated production of dimethyl sulfide (DMS) by two clones of Emiliania huxleyi, Limnol. Oceanogr., 4, 151-1160, 1996.

Yoch, D. C.: Dimethylsulfoniopropionate: Its sources, role in the marine food web, and biological degradation to dimethylsulfide, Appl. Environ. Microbiol., 68, 5804-5815, https://doi.org/10.1128/AEM.68.12.5804-5815.2002, 2002.

Yoch, D. C., Ansede, J. H., and Rabinowitz, K. S.: Evidence for intracellular and extracellular dimethylsulfoniopropionate (DMSP) lyases and DMSP uptake sites in two species of marine bacteria, Appl. Environ. Microbiol., 63, 3182-8, 1997.

Zubkov, M. V., Fuchs, B. M., Archer, S. D., Kiene, R. P., Amann, R., and Burkill, P. H.: Rapid turnover of dissolved DMS and DMSP by defined bacterioplankton communities in the stratified euphotic zone of the North Sea, Deep-Sea Res. Pt. II, 49, 30173038, https://doi.org/10.1016/S0967-0645(02)00069-3, 2002. 